\title{
1 Effects of seasonal closures in a multi-specific fishery
}

2

3 Mohamed Samy-Kamal $^{\mathrm{a} *}$, Aitor Forcada ${ }^{\mathrm{ab}}$ and Jose Luis Sánchez Lizaso ${ }^{\mathrm{ac}}$.

4

5 a* Corresponding Author: Tel: +34 965903400 Ext. 2916; E-mail: mohamedsamy@ua.es

$6 \quad{ }^{b}$ E-mail: forcada@ua.es

$7 \quad{ }^{\mathrm{c}}$ E-mail: jl.sanchez@ua.es

8

9 a Departamento de Ciencias del Mar y Biología Aplicada, Universidad de Alicante, PO Box 99, Edificio

10 Ciencias V, Campus de San Vicente del Raspeig, E-03080 Alicante, Spain.

11

12

13

14

15

16

17

18

19

20

21

22

23

24

25

26 
In input-controlled multi-specific fisheries, seasonal closure has little biological rationale as a management measure, because it is difficult to adjust such closure for many target species and, in most cases, they are adopted for economic purposes. We aimed to determine effects of closure in biologic and economic terms, using 10-year landing data from two representative trawling ports of the Western Mediterranean: Dénia and La Vila Joiosa. Analysis of Variance (ANOVA) was used to detect significant differences, before and after the closure, in standardized catch per unit effort (CPUE) at different seasons and sale prices at home/closed and neighbour/open ports. ANOVAs showed significantly higher CPUE after the closure for total landings and Mullus spp. of the Red mullet métier, M. merluccius CPUE (in two years) and the total landings of the Norway lobster métier. On the contrary, significant lower values were observed after the closure for total CPUE (in early summer) and A. antennatus of Red shrimp métier. Similar CPUE was observed at all levels when the closure took place in late summer. In economic terms, market prices of target species have decreased or shown no changes after the closure at home/closed and neighbouring/open ports. The only exception was the significant increase of the price for A. antennatus in positive biological effects on some target species. However, closure leads to an unavoidable reduction in most of target species prices. An alternative management measure that is based on effort reduction in input-controlled multi-specific fisheries could ban one day per week when market prices of target species are lower.

Key words: Catch per unit effort (CPUE), Effort reduction, Evaluation of closures, Ex-vessel price, fisheries management, management measures, and trawl fishery. 


\section{Introduction}

A large number of fish stocks are overexploited in Mediterranean multi-specific fisheries, and reductions of fishing mortality on these stocks are often recommended (FAO, 2011). Fishing mortality is normally

57 reduced through effort reductions, which can mainly be done by decreasing the number of vessels or the 58 fishing days. The adoption of closed fishing seasons is one of the simplest measures used in the 59 management of fisheries. Closure means a complete cessation of fishing activity for a certain period, which results in a reduction of annual effort (Lleonart and Franquesa, 1999). This management strategy is mainly based on effort control which reduces fishing intensity and protects target stock from mortality at a specific stage of the life history, i.e. when a species aggregates in an area or in a specific season to spawn (Horwood et al., 1998; Dinmore et al., 2003). This approach also can help reproductive success and support recruitment (Arendse et al., 2007). However, it is well-known that in multi-species fisheries, such as the Mediterranean Sea, there are many target species with different recruitment and reproduction periods. Consequently, a particular period may help the recruitment or the reproduction of certain species

67 and not others (Lleonart and Franquesa 1999). Therefore, in Mediterranean multi-specific fisheries, the adoption of closure, in some cases, is based on economic purposes in agreement with fishermen (Lleonart and Franquesa, 1999).

70

71 From an economic perspective, a temporary/seasonal closure may have short-term benefits to fishermen:

72 (i) the reduction of operating costs; (ii) financial compensation arising from the recovery of stocks where

73 fishing has ceased; and (iii) compensation subsidies (if the administration funds the closure) (Lleonart and 74 Franquesa, 1999). However, ceasing the fleet for long periods (e.g. monthly closure) results in serious 75 logistical and economic problems, namely: (i) fishermen unemployment during the closure period; (ii) 76 "border effect" the result of imbalances between the fleet activity belonging to adjacent ports without 77 closure (Lleonart and Franquesa, 1999); (iii) the market for some luxury species becoming devoid of 78 highly appreciated local products (Guillen and Maynou, 2014); (iv) imbalances in market price due to the 
79 irregular supply of fish to the market (Guerra-Sierra and Sánchez-Lizaso, 1998); and (v) rise in 80 administration cost in the form of state subsidies.

82 Closure in Mediterranean multi-specific fisheries have a little biological rationale because it is very 83 difficult to adjust the closure to reproductive periods of many target species (Table 1) (Lleonart and 84 Franquesa, 1999); also it generates some logistic problems (Guerra-Sierra and Sánchez-Lizaso, 1998; 85 Lleonart and Franquesa, 1999; Guillen and Maynou, 2014). The closures are not intended to protect 86 spawning stock at a vulnerable point in their life cycle, thereby enhancing the probability of sustaining 87 recruitment; rather, they are adapted generally for economic purposes and reducing effort intensity. 88 Closures can be justified in multi-specific fisheries if it results in substantial biological or economic 89 benefits, other than effort reduction. These benefits can be seen by increases in landings (e.g. in $\mathrm{kg}$ or in 90 first sale price) that compensate some of the previously mentioned problems. Otherwise, effort reduction 91 can be achieved by adopting other less-problematic management measures rather than closure, i.e. 92 reduction of fishing days or hours.

94 Temporary/seasonal closures are widely studied in many fisheries throughout the world (e.g. Ye et al., 95 1998; Pipitone et al., 2000; Arendse et al., 2007; Shih et al., 2009). For instance, in the Gulf of 96 Castellammare (NW Sicily, Mediterranean Sea), Pipitone et al. (2000) addressed that temporary closure 97 based on year-round trawling bans, may prove useful especially for multispecies and multigear artisanal 98 fisheries. Studies in the Western Mediterranean are limited to ecological effect on epibenthic communities 99 (Demestre et al., 2008) and on catch composition in the Catalan Sea (Sánchez et al., 2007). In the 100 Adriatic and the Catalan Seas, Demestre et al. (2008) reported a decrease of epibenthic faunal abundance 101 with the resumption of fishing activity after the closure at both fishing grounds. Further in both Seas, the 102 species composition of both the retained and discarded fractions was analysed by Sánchez et al. (2007), 103 where in both fishing grounds the retained fraction was slightly higher in the high fishing intensity 104 periods than in the low intensity ones. Thereby the effectiveness of specific temporary/seasonal closures 
as the most applied management measure for multi-specific fisheries should be rigorously evaluated in both biological and economic terms using long-term landings data. In addition, there are many target species with different recruitment and reproduction periods; thus the timing of the closure should be taken into account as suitable timing may or may not benefit particular species.

The aim of this work was to determine the effect of seasonal closure in biological (total landings and 111 landings of target species) and economic (ex-vessel prices "first sale price" of target species) terms, in a commercial Spanish trawling fishery. The data were derived from two representative fishing ports (Dénia and La Vila Joiosa) in the Western Mediterranean.

\section{Material and Methods}

\subsection{Study area}

This study was conducted in two ports, Dénia and La Vila Joiosa, located in the Southwestern Mediterranean Sea off the coast of Spain (Fig. 1). Along the gulf of Alicante, there are 12 fishing ports that have traditionally been important fishing activity locations. According to the number of trawlers,

122 these two ports represent about $41 \%$ of the total trawlers operating on the Alicante coast (BOE, 2013).

123 They can be considered quite representative of this area, given the similarity of the characteristics of the

124 trawlers, and also have features similar to those operating in other areas of the Western Mediterranean 125 (Samy-Kamal et al., 2014). The Mediterranean trawl fishery in Spain is an input-controlled fishery, where 126 effort is controlled by limiting the time at sea: fishing is permitted for 12 hours/day from Monday to 127 Friday, stopping the fishing activity completely on weekends (Maynou et al., 2006). The fishing activity 128 is ceased normally for one month per year as seasonal closures, alternating the North ports (e.g. Dénia) 129 with the south ports (e.g. La Vila Joiosa) to avoid the closure of the whole gulf at once (Table 2). The species Mullus spp. (Linnaeus, 1758), Merluccius merluccius (Linnaeus, 1758), Nephrops norvegicus 
131 (Linnaeus, 1758) and Aristeus antennatus (Risso, 1816) are the most targeted by fishermen and accounted

132 for almost $60 \%$ of the total income and $24 \%$ of the total weight in the fishery (Samy-Kamal et al., 2014;

133 2015a). In regards to stocks, in general, the Mediterranean and Black Sea had 33\% of assessed stocks

134 fully exploited, while the great bulk (50\%) overexploited (FAO, 2011). Almost all demersal fish and 135 crustaceans stocks assessed were classified as overexploited including the four target species studied 136 herein (FAO, 2011).

\subsection{Data collection}

Two different data sets were used, one for each port. Data records of daily auctions were obtained from the fishing guild of each port for 10 years (2002 to 2011). For each fishing day, data on species landing

142 weight $(\mathrm{kg})$ and its first sale value $(€)$ were available by vessel. Sale value (revenue) is the result of 143 quantity landed $(\mathrm{kg})$ and ex-vessel fish price (price obtained by fishers per $\mathrm{kg}$ of landed fish). The sale 144 value $(€)$ of each target species was divided by its landings $(\mathrm{kg})$ to calculate the first sale price per $\mathrm{kg}$ (exvessel fish price). Vessels with sporadic landings events (less than 3 years, and less than 3 months/year) within the ports were excluded from the analysis, considering only those vessels registered in the studied

147 ports (home port) to avoid possible biases in the data. Most of the included vessels have had activity 148 throughout the considered period. The total number of collected samples (vessel/day) was 102187 fishing 149 days. Technical characteristics of vessels within the analysis were obtained from the Census of Fleet 150 Operations of the General Secretariat of Maritime Fisheries of Spain (BOE, 2013). Over the 10 years 151 studied, a total of 93 different fishing vessels were listed in the official fleet register of Dénia and La Vila 152 Joiosa (34 and 59 vessels respectively). The bulk of the fleet is composed of vessels up to 23-25 m length, 153 40-80 GT, 40-60 GRT and 200-400 registered HP (Samy-Kamal et al., 2014).

\subsection{Data standardization}


For multi-specific fisheries, a preliminary analysis of the fishing tactics in the fishery is essential to clearly determine the real effort directed at the species under study (Maynou et al., 2003). Four principal métiers, Red mullet, European hake, Norway lobster and Red shrimp, were identified based on catch profiles and the main target species, using the multivariate analysis: cluster, nMDS and SIMPER (Samy-Kamal et al., $2014 ; 2015)$. Catch rates were standardized to separate that large percentage of the variability of data not directly attributable to variations in abundance. To standardize the catch per unit effort (CPUE), generalized linear models (GLM) were used (Maynou et al., 2003; Maunder and Punt, 2004; Murawski et al., 2005). A minimum threshold of effort by vessel of 100 fishing days per year was considered; also, a selection of vessels operating in the fishery for more than 4 years was carried out with the intention of standardizing CPUE data from vessels that would be representative of the fishery. Once the selection of representative vessels was undertaken, a data matrix by métier was constructed with the variables required for analysis. The initial set of explanatory variables considered was: temporal variables (Year and Month) to capture temporal variations; technical variables (vessel's total length " $T L$ " and gross tonnage "GT") to capture differences between vessel characteristics; and the "individual Vessel" was also 171 used as an alternative in case if technical factors were not significant. Regarding the "individual Vessel" 172 factor in the analysis of Mediterranean fisheries CPUE, various authors have used vessel factor, grouped 173 into categories according to their technical characteristics (Goñi et al., 1999), while others have used the 174 "individual Vessel" factor (Maynou et al., 2003; Sbrana et al., 2003). In the Mediterranean small and 175 medium-scale fisheries, the experience and skills of the fishermen determine and influence the result of 176 fishing operations. This fact justifies that it is more appropriate to include the factor "individual Vessel" in 177 the models separately, rather than grouped into categories (Maunder and Punt, 2004). The "individual 178 Vessel" factor includes other factors that are not directly related to the technical characteristics of the 179 vessels, but that may influence catch rates (Maynou et al., 2003). The initial model applied contains all 180 factors, considering Year, Month and Vessel as factor, while $T L$ and GT as variables: CPUE $\sim$ Year + 181 Month $+T L+G T+$ Vessel 
183 The GLM was conducted on the total CPUE $\left(\mathrm{kg} \cdot \operatorname{vessel}^{-1} \cdot\right.$ day $\left.^{-1}\right)$ as well as the CPUE of each target 184 species (Mullus spp., M. merluccius, N. norvegicus and A. antennatus) in their respective métier. When 185 the data was asymmetric, log transformation was made to correct the extreme data and the constant $\mathrm{K}$ was 186 added to the catch rate to account for zero observation, where: $\mathrm{K}$ is $10 \%$ of the mean CPUE. For each 187 case, i.e. total CPUE and by each target species, the best model were fitted with a stepwise selection 188 procedure by exact Akaike Information Criterion (AIC; Akaike, 1974), and factors that were not 189 significant were eliminated from the model. The AIC determines between adding or excluding each variable, creating a balance between the variability explained by each factor and the degrees of freedom introduced in the model (Akaike, 1974). After the models were fitted, the significance of each factor was analysed using F-values. Finally, we derived calibration coefficients by back-transforming the parameter estimates (Quinn and Deriso, 1999) and transformed CPUE data by dividing the raw CPUE by the appropriate coefficient.

\subsection{Analysis of Variance}

To analyse the biological and economic effect of closure at the home/closed port, data of five years, where the closure occurred in early and late summer, were selected for the analysis (Table 2), in which two weeks before and two weeks after the closure were used. For the economic effect at the neighbour/open port, two weeks before, two weeks during and two weeks after the closure data were compared. Analysis of Variance (ANOVA) was used to test for significant differences in total standardized CPUE $\left(\mathrm{kg} \cdot\right.$ vessel $^{-\mathbf{1}} \cdot$ day $^{\mathbf{- 1}}$ ) and standardized CPUE of target species by métier (biological

204 effect), and first sale price of target species (euro $\cdot \mathrm{kg}^{-1}$ ) at home and neighbour/open port (economic 205 effect) (Underwood, 1997). The experimental design for the biological analysis consisted of three factors:

206 Closure (fixed); Season (fixed and orthogonal); and Year (random and orthogonal). The same 207 experimental design was used for the economic analysis, replacing the factor Season by the factor Port. 208 An even numbers of samples were randomly selected to maintain balanced data within each level of the 
factors considered in the experimental design. However, métiers are known to exhibit seasonality, in

210 many occasions "disappearing" in some years (during the studied two weeks before and after the closure).

211 Therefore, levels number of factor Year and minimum samples used to balance the model varied (Table

212 3). The temporal factor Year was considered as orthogonal to separate the inter-annual variations from the

213 effect of the closure. Factor Season was used to separate the effect of season from closure, while factor

214 Port accounted for the relation between both ports and first sale price of target species. When the

215 ANOVA F-test was significant, post hoc analyses were conducted using Student-Newman-Keuls (SNK)

216 multiple comparisons (Underwood, 1981). Before ANOVA analysis, Cochran's test was used to test for

217 homogeneity of variance (Cochran, 1951). When significant heterogeneity was found, the data were

218 transformed by $\sqrt{ }(x+1)$ or $\ln (x+1)$. When transformations did not remove heterogeneity, analyses were

219 performed on the untransformed data, with the F-test $\alpha$-value set at 0.01 (Table 5 and 6), since ANOVA is

220 more restricted to departures from this assumption, especially when the design is balanced and contains a

221 large number of samples/treatments (Underwood, 1997). All analysis (ANOVA and GLM) were

222 conducted by R statistical computing software (R Development Core Team, 2010) and the R's package

223 GAD (Sandrini-Neto and Camargo, 2011).

224

2253 Results

226

\section{3.1. Data standardization}

228

229 The GLMs were able to separate the percentage of data variability that do not account for abundance. The

230 variability explained by the model were between $27.51 \%$ and $55.20 \%$ for total CPUE and target species

231 CPUE of Red mullet, European hake and Norway lobster métiers (Table 4). The factor Vessel contributed

232 to separate the highest percentage of deviance in CPUE in most cases (e.g. $38.30 \%$ for M. merluccius

233 CPUE). In addition, factors Month and Year also were highly significant in most cases (e.g. 15\% for

234 Norway lobster CPUE), which clearly captured the temporal variability in the catchability of the target 
species. In contrast, the explained variance in Red shrimp métier was about 23 to 33\% (Table 4). This

236 suggests that factors other than the used variables cause most of the variability within the CPUE data. In

237 this métier, technical factors as well as Vessel account for the most (i.e. $31 \%$ for the total CPUE) of the 238 explained variability. The models within the last 5 AIC values of the best model, in each case, are 239 reported in Appendix 1. Also the resulting coeffecients used for standardization are reported in Appendix $240 \quad 2$ and 3.

\subsection{Biological effect}

In general, trends in CPUEs were higher after the closure, except for the Red shrimp métier. For total landings and Mullus spp. of Red mullet métier, significant higher CPUEs were observed after the closure in both seasons, early and late summer (Fig. 2a and 2b) (Table 5).

Slightly increasing trends of CPUEs were observed after the closure in total landings and M. merluccius of European hake métier, in both seasons (Fig. 2c and 2d). For total landings, significant inter-annual variations were detected, while no effects were observed for the closure (Table 6). M. merluccius CPUE

251 showed significant two-way interactions between Closure and Year, as well as between Season and Year 252 (Table 6). In SNK comparisons, significant higher CPUE after the closure were detected in 2006 and 2532007.

For Norway lobster métier, clear increasing trends were observed after the closure at both total and target species levels (Fig. 2e and 2f), but this difference was only significant for total landings (Table 6).

On the contrary, decreasing trends of CPUEs in Red shrimp métier were observed after the closure mainly 259 in early summer (Fig. 2g and 2h). At species level, A. antennatus CPUEs significantly decreased after the 260 closure in both seasons (Table 6). For the total landings the two-way interaction between Closure and 
Season was significant (Table 6). In SNK comparisons, significant lower CPUEs were obtained after the closure in early summer, while CPUEs in late summer were similar before and after the closure.

\subsection{Economic effect}

For the first sale price of Mullus spp. at the home/closed port, a slight decrease was observed in Dénia in contrast to a slight increase in La Vila Joiosa (Fig. 3a). In ANOVAs, the two-way interaction of Closure and Port was significant (Table 5). In SNK comparisons, price decreased significantly after the closure in Dénia, while no differences were detected in La Vila Joiosa. At neighbour/open port, a mild decreasing trend was observed by the closure at both ports (Fig. 3b). In ANOVAs, the three-way interaction was significant (Table 5), where the price in La Vila Joiosa was significantly higher before the closure (in Dénia) than during and after the closure in the 3 years studied (Fig. 3b). In Dénia, the same differences were detected but only in 2010 .

For M. merluccius, home/closed port prices showed a small reduction after the closure in Dénia and similar prices in La Vila Joiosa (Fig. 3c). ANOVAs indicated that the interaction between Closure and Year was significant (Table 6), showing higher price before, as opposed to after, the closure only in 2006. Inter-annual variation was detected as the interaction between Port and Year was also significant. At neighbour/open port, slight increase of prices was observed in Dénia during the closure in La Vila Joiosa and vice versa (Fig. 3d), although ANOVA did not show any significant differences (Table 6).

For $N$. norvegicus, at home/closed port, similar mean prices were observed in Dénia before and after the closure, in contrast to a slight decrease in La Vila Joiosa (Fig. 3e). In ANOVAs, the three-way interaction was significant (Table 6). Mean prices were significantly higher in Dénia before the closure only in 2007 and 2010, while in La Vila Joiosa, such differences were not significant (Fig. 3e). At neighbour/open port, 
evident in La Vila Joiosa, as prices decreased during the closure in Dénia. No effect was detected in ANOVA for closure or port, while inter-annual significant differences were present (Table 6).

Finally for A. antennatus, at home/closed port, a clear price reduction was observed in Dénia after the closure, while a small increase was observed in La Vila Joiosa (Fig. 3g). In ANOVAs, there were

292 significant two-way interactions between Closure and Year, as well as between Closure and Port (Table

293 6). Three years showed significant lower mean price after the closure. Price also decreased after the 294 closure in Dénia, while no significant differences were detected in La Vila Joiosa (Fig. 3g). At 295 neighbour/open port, a clear higher mean price in Dénia was observed during the closure in La Vila 296 Joiosa (Fig. 3h), while a small decreasing trend was detected in La Vila Joiosa. The three-way interaction 297 was significant (Table 6). Higher mean price in Dénia was observed during, after and before the closure 298 in La Vila Joiosa, in all years (Fig. 3h). However, prices in La Vila Joiosa did not show any effect by the 299 closure in Dénia.

\section{Discussion}

The resumption of fishing activity, in both study ports, did not always result in higher CPUE after the closure. Generally, increasing trends were observed in Red mullet, European hake and Norway lobster métiers at both total and target species CPUEs. However, the statistical analysis revealed significant differences only for total landings and Mullus spp. CPUE of Red mullet métier, M. merluccius CPUE (in two years) and the total landings of Norway lobster métier. On the contrary, Red shrimp métier showed a negative effect of significantly lower CPUE at both total landings (in early summer) and A. antennatus CPUE. In economic terms, market prices of the main target species have decreased or shown no changes after the closure at home/closed and neighbour/open ports. The only exception was the increased $A$. antennatus price in Dénia during the closure in La Vila Joiosa. 
Standardized catch rates assumes that the total length, gross tonnage and individual vessel were able to separate a large percentage of the variability of the data is not directly attributable to variations in abundance. While the year, month and vessel mainly explained the total variance percentages ranging between $23 \%$ (in the case of Red shrimp metier) and 55\% (in European hake metier). Nevertheless, these

317 percentages are very high despite considering daily CPUE data instead of monthly average. The 318 percentages obtained by the models reflect the suitability of the selected factors. One way to decrease the 319 variability of the data, and therefore increase the variability explained by the model, is to aggregate the 320 data on a temporary basis; for example, monthly (Goñi et al., 1999; Maynou et al., 2003). For our case of 321 study, such aggregation was not useful because we wanted to see differences in CPUE to the lower time 322 scale, so we decided to keep the analysis on daily basis. More research is needed on individual species, 323 fishing technology, and the environment to determine what factors are most influential in determining 324 CPUE. Mahévas et al. (2011) observed that the importance of the skipper/crew experience effect is weaker than the technical effect of the vessel and its gear. Also reported that, other information (e.g. length of headline, weight of otter boards, or type of groundrope) should be taken into account to improve 327 the modelled relationships between CPUE and the variables that measure relative fishing power (Mahévas 328 et al., 2011). Other factors such as the swept area, doors open, travelled distance, gear depth may greatly 329 influence catch rates. However, we did not have these data, so it could not be included.

331 Fishing closures during spawning season can most likely reduce fishing mortality if the spawning stock is 332 more aggregated during the spawning season than at any other time of the year; however, in a multi333 specific fishery, this not the case of all target species. The spawning seasons of the four main target 334 species are summarized in Table 1. Adjusting the closure to benefit all target species in multi-specific 335 fisheries is difficult. Changes were observed in the CPUE of three main target species, as Mullus spp. and 336 M. merluccius increased after the closure, while A. antennatus decreased. A rise in total landings of Red 337 mullet and Norway lobster métiers has been also observed. The European hake M. merluccius represents 338 a spawning period extending almost throughout the year that is interpreted as an adaptive strategy to 
maximize the survival of early life cycle stages (Martin et al., 1999; Domínguez-Petit, 2008). This largescale spawning period has favoured the observed benefits. The reproduction of Red mullet Mullus spp. (both Mullus barbatus and Mullus surmuletus) in the western Mediterranean occurs mainly between 342 spring and summer, almost exclusively from May to July (Relini et al., 1999; Voliani, 1999; Sieli et al., 343 2011) which also has favoured the observed increase. In contrast, the spawning period of A. antennatus 344 occurs between the months of May to October, but is more intense in July and August (Demestre, 1995; 345 García Rodríguez and Esteban, 1999). Although the spawning period concurs with the closure in early summer, decreased catches have been observed.

Moreover, a short closure period (one month) cannot substantially raise biomass due to an increase of the abundance of individuals; while it could be solely due to the increase of fish weight. An explanation of the increased CPUE after one month of closure is linked to rapid-growing species, observed in Mullus spp., M. merluccius (Piñeiro and Sainza, 2003) and total landings of Norway lobster métier, where species such as Micromesistius poutassou and Phycis blennoides are abundant (Samy-Kamal et al., 2014). But these closures are too short to affect benthic communities, where these processes, recruitment and growth take place much more slowly (Demestre et al., 2008). From another perspective, Bas (2006) argued that the effect of closure, reflected in an increase of catches following resumption of the activity, is more likely due to species' behavior. The absence of fishing activity changes the species' behavior to move around freely, thus occupying more places, having previously been accustomed to escaping into marginal places during the fishing activity (Bas, 2006). After reopening the fishery, it is likely these species are more susceptible to being caught. This is more evident in limited fisheries, such as continental-shelf métiers, especially for fishes (e.g. Mullus spp. and M. merluccius) as they are more mobile than benthic communities which could be another explanation of the results obtained here. Similar changes in fish 362 behaviour after closure have been reported elsewhere (Jupiter et al., 2012; Januchowski-Hartley et al., 363 2014). For instance, Jupiter et al. (2012) observed that the main observed impact of the closure was the decline of large-bodied species. This has reflected in differences in community composition as well as the 
prevalence of small herbivores species, as a consequence of a decline in territorial aggression from the removal of large species (Jupiter et al., 2012). Also they suggested that the substantial benefits to fisheries from closures, when occurred, can be removed in a very short time period through focused fishing efforts.

368 Similarly, in the Gulf of Alicante, Samy-Kamal et al. (2014) have observed peaks in the fishing effort 369 intensity in both August and October are mainly associated with the reopening of the fishery after the 370 temporal closure.

372 In the short term, a closure may also involve losses, such as those derived from a reduction in sales or loss 373 of markets (Lleonart and Franquesa, 1999). Prices are a function of supply and demand, and are 374 influenced by fish size, species, consumer preferences, fish quality and the catch quantity-demand 375 function (McClanahan, 2010). Prices of most target species decreased by the closure, which may be 376 related to loss of market due to shortage in the supply after a month of closure. The economic effect of 377 closure at the neighbour/open port was not so evident, except for the increase of $A$. antennatus price in 378 Dénia during the closure in La Vila Joiosa. This is explained as closure might produce more demand on the market at Dénia where A. antennatus is the main target species.

381 According to the results obtained here, the closure has one apparent benefit, which is the overall reduction 382 of fishing effort for that specified period. The seasonal closure reduces the fishing effort (fishing pressure) 383 about $8.33 \%$ (one month per year) of the annual effort, which is the only apparent benefit. Despite this, 384 choosing the suitable timing to schedule closure during the spawning season of the main target species is 385 difficult; it would bring up some biological positive effects on some target species (e.g. Mullus spp. and 386 M. merluccius). Notwithstanding, these increases in catches after the closure are so far to compensate the 387 lost catches by stopping the activity for a whole month. In addition, closures more likely lead to 388 unavoidable reduction in market prices of many target species. An effective management measure should 389 be easily applied, as in the case of seasonal closure, and be able to ensure enough net contribution to the 390 income of fishers. At the same time, an economically consistent closure should be applied without 
391 subsidies and be accepted by the fishing community; otherwise, it will convert into a structural 392 compensation and will lose its economic sense (Lleonart and Franquesa, 1999). Despite these reductions 393 in prices, the wide acceptance of seasonal closure as a management measure by the fishing community is 394 mainly because it is subsidized by the administration. An alternative management measure, based on 395 effort reduction in input-controlled Western Mediterranean multi-specific fisheries, could target a day per 396 week (other than weekend) when market prices of target species are lower (Guillen and Maynou, 2014; 397 Samy-Kamal et al., 2015b). This would result in the double annual amount of effort reduction, as well 398 minimize the short-term negative economic effect of seasonal closure on market prices and therefore on 399 fishers' income. Also, it is more acceptable by the fishing community to stop fishing for one day than a 400 whole month, and can be easily applied without additional costs of subsidies.

401

\section{Acknowledgements}

403

The authors acknowledge the cooperation of the staff at La Vila Joiosa and Dénia fishermen's guilds for their important role in collecting the data. M. Samy-Kamal was supported by a grant of the Spanish Agency for International Development Cooperation (AECID). We acknowledge Julie Smith and Kelly

407 Bucas for language revisions. We also extend our thanks to Dr. Jesus Jurado-Molina for his help on the R 408 script. We are also grateful to the two reviewers and the editor whose comments greatly improved the 409 manuscript. We thank the FAO for species drawings for figures 2 and 3.

\section{References}

413 Akaike, H. 1974. A new look at the statistical model identification. EEE Transactions on Automatic 414 Control 19: 716-723. 
Arendse, C. J., Govender, A., and Branch, G. M. 2007. Are closed fishing seasons an effective means of

417 increasing reproductive output? A per-recruit simulation using the limpet Cymbula granatina as a case

418 history. Fisheries research, 85(1): 93-100.

419

Bas, C. 2006. The Mediterranean Sea: living resources and exploitation. CIHEAM-IAMZ.

421

422 BOE. 2013. Boletin Oficial del Estado. Ministerio de Agricultura, Alimentación y Medio Ambiente.

423 Resolución de 27 de marzo de 2013, de la Secretaría General de Pesca, por la que publican los censos

424 actualizados de las modalidades de arrastre de fondo, artes menores, cerco y palangre de fondo del 425 caladero Mediterráneo.BOE nº 88, Sec. III. Pág. 27442.

426

427 Cochran, W.G. 1951. Testing a linear relation among variances. Biometrics 7:17-32

428

429

Demestre, M. 1995. Aristeus antennatus (Decapoda: Dendrobranchiata). Marine Ecology Progress Series, 430 127: 57-64.

431

432 Demestre, M., de Juan, S., Sartor, P., and Ligas, A. 2008. Seasonal closures as a measure of trawling 433 effort control in two Mediterranean trawling grounds: effects on epibenthic communities. Marine 434 pollution bulletin, 56(10): 1765-1773.

436 Dinmore, T. A., Duplisea, D. E., Rackham, B. D., Maxwell, D. L., and Jennings, S. 2003. Impact of a 437 large-scale area closure on patterns of fishing disturbance and the consequences for benthic communities. 438 ICES Journal of Marine Science: Journal du Conseil, 60(2): 371-380. 
441 in size at maturity of European hake Atlantic populations in relation with stock structure and 442 environmental regimes. Journal of Marine Systems, 71(3): 260-278.

444 FAO. 2011. Review of the state of world marine fishery resources. FAO Fisheries and Aquaculture 445 Technical Paper No. 569. Rome, FAO. 2011. 334 pp.

446

447 448 449 450

451 452 453 454 455 456

457 Guerra-Sierra, A., and Sánchez-Lizaso, J. L. 1998. Fundamentos de Explotacion de Recursos Vivos Marinos. Ed. Acribia, Zaragoza, Spain. 249 pp.

458 Guillen, J., and Maynou, F. 2014. Importance of temporal and spatial factors in the ex-vessel price 459 formation for red shrimp and management implications. Marine Policy, 47: 66-70.

461 Horwood, J. W., Nichols, J. H., and Milligan, S. 1998. Evaluation of closed areas for fish stock 462 conservation. Journal of Applied Ecology, 35(6): 893-903. 
Januchowski-Hartley, F. A., Cinner, J. E., and Graham, N. A. 2014. Fishery benefits from behavioural 465 modification of fishes in periodically harvested fisheries closures. Aquatic Conservation: Marine and 466 Freshwater Ecosystems, 24(6): 777-790.

467

Jupiter, S. D., Weeks, R., Jenkins, A. P., Egli, D. P., and Cakacaka, A. 2012. Effects of a single intensive 469 harvest event on fish populations inside a customary marine closure. Coral Reefs, 31(2): 321-334.

470

471 Lleonart, J., and Franquesa, R. 1999. La veda como medida de gestión. $4^{\text {a }}$ Reunión del Foro Científico 472 sobre la pesca española en el Mediterráneo Málaga, junio, 1999.

473

474 Mahévas, S., Vermard, Y., Hutton, T., Iriondo, A., Jadaud, A., Maravelias, C.D., Punzón, A., Sacchi, J., 475 Tidd, A., Tsitsika, E., Marchal, P., Goascoz, N., Mortreux, S., Roos, D. 2011. An investigation of human 476 vs. technology-induced variation in catchability for a selection of European fishing fleets. ICES J. Mar. 477 Sci. 68, 2252-2263.

478

479 Martin, P., Sartor, P., and García-Rodríguez, M. 1999. Exploitation patterns of the European hake 480 Merluccius merluccius, red mullet Mullus barbatus and striped red mullet Mullus surmuletus in the 481 western Mediterranean. Journal of Applied Ichthyology, 15(1): 24-28.

Maynou, F., Sardà, F., Tudela, S., and Demestre, M. 2006. Management strategies for red shrimp 484 (Aristeus antennatus) fisheries in the Catalan Sea (NW Mediterranean) based on bioeconomic simulation 485 analysis. Aquatic Living Resources, 19(2): 161-172. McClanahan, T. R. 2010. Effects of fisheries closures and gear restrictions on fishing income in a Kenyan 488 coral reef. Conservation Biology, 24(6): 1519-1528. 
Massutí, E., and Reñones, O. 2005. Demersal resource assemblages in the trawl fishing grounds off the

491 Balearic Islands (western Mediterranean). Scientia Marina, 69(1): 167-181.

492

493 Maunder, M.N., Punt, A.E., 2004. Standardizing catch and effort data: a review of recent approaches.

494 Fisheries Research, 70: 141-159.

495

496 Maynou, F., Demestre, M., and Sanchez, P. 2003. Analysis of catch per unit effort by multivariate 497 analysis and generalised linear models for deep-water crustacean fisheries off Barcelona (NW 498 Mediterranean). Fisheries Research, 65: 257-269.

499

500

Murawski, S.A., Wigley, S.E., Fogarty, M.J., Rago, P.J., and Mountain, D.G. 2005. Effort distribution 501 and catch patterns adjacent to temperate MPAs. ICES Journal of Marine Science, 62: 1150-1167.

502

503

Piñeiro, C., and Sainza, M. 2003. Age estimation, growth and maturity of the European hake (Merluccius 504 merluccius (Linnaeus, 1758)) from Iberian Atlantic waters. ICES Journal of Marine Science: Journal du 505 Conseil, 60(5): 1086-1102.

506

507 Pipitone, C., Badalamenti, F., D’Anna, G., and Patti, B. 2000. Fish biomass increase after a four-year 508 trawl ban in the Gulf of Castellammare (NW Sicily, Mediterranean Sea). Fisheries Research, 48: 23-30. 509

510 Quinn II, T.J., Deriso, R.B., 1999. Quantitative Fish Dynamics. Biological Resource Management Series. 511 Oxford University Press, New York. 542 pp.

513 R Development Core Team., 2010: R: A language and environment for statistical computing. R 514 Foundation for Statistical Computing, Vienna, Austria. ISBN 3-900051-07-0, URL http://www.R515 project.org/. 
517 Relini, G., J. Bertrand, A. and Zamboni. 1999. Synthesis of the knowledge on Bottom Fishery Resources 518 in Central Mediterranean (Italy and Corsica). Biologia Marina Mediterranea, 6(Supl. 1): 1-868.

520 Samy-Kamal, M., Forcada, A., and Sánchez-Lizaso, J.L. 2014. Trawling fishery of the western 521 Mediterranean Sea: Métiers identification, effort characteristics, landings and income profiles. Ocean \& 522 Coastal Management, 102: 269-284.

523

524 Samy-Kamal, M., Forcada, A., and Sánchez-Lizaso, J.L. 2015a. Short-term effect of selectivity change in 525 a trawling fishery in the Western Mediterranean. Journal of Applied Ichthyology, 31: 265-275.

526

527 Samy-Kamal, M., Forcada, A., and Sánchez-Lizaso, J.L. 2015b. Daily variation of fishing effort and ex528 vessel prices in a western Mediterranean multi-species fishery: implications for sustainable management. 529 accepted. Marine policy.

530

531 Sánchez, P., Sartor, P., Recasens, L., Ligas, A., Martin, J., De Ranieri, S., and Demestre, M. 2007. Trawl 532 catch composition during different fishing intensity periods in two Mediterranean demersal fishing 533 grounds. Scientia Marina, 71(4): 765-773.

535 Sandrini-Neto, L., and Camargo, M.G. 2011. GAD: an R package for ANOVA designs from general 536 principles. Available on CRAN.

538 Sardà, F. 1991. Reproduction and Moult Synchronism in Nephrops norvegicus (L.)(Decapoda, 539 Nephropidae) in the Western Mediterranean: Is Spawning Annual or Biennial? Crustaceana, 186-199. 
541 Sbrana, M., Sartor, P., and Belcari, P. 2003. Analysis of the factors affecting crustacean trawl fishery

542 catch rates in the northern Tyrrhenian Sea (western Mediterranean). Fisheries research, 65(1): 271-284.

543

544 Shih, N. T., Cai, Y. H., and Ni, I. H. 2009. A concept to protect fisheries recruits by seasonal closure 545 during spawning periods for commercial fishes off Taiwan and the East China Sea. Journal of Applied 546 Ichthyology, 25(6): 676-685.

547

548 Sieli, G., Badalucco, C., Di Stefano, G., Rizzo, P., D’Anna, G., and Fiorentino, F. 2011. Biology of red 549 mullet, Mullus barbatus (L. 1758), in the Gulf of Castellammare (NW Sicily, Mediterranean Sea) subject 550 to a trawling ban. Journal of Applied Ichthyology, 27(5): 1218-1225.

551

552 Underwood, A.J. 1981. Techniques of analysis of variance in experimental marine biology and ecology. 553 Oceanography and Marine Biology: An Annual Review, 19: 513-605.

554

555 Underwood, A.J. 1997. Experiments in ecology: their logical design and interpretation using analysis of 556 variance. Cambridge University Press, Cambridge.

557

558 559 using a length-based yield-per-recruit model. ICES Journal of Marine Science: Journal du Conseil, 55(6):

560 $1112-1124$.

561

562

563

564

565

566 
569 Table 1. Spawning (gray cells) periods of the main target species: Mullus spp. Merluccius merluccius,

$570 \quad$ Nephrops norvegicus and Aristeus antennatus by month.

571

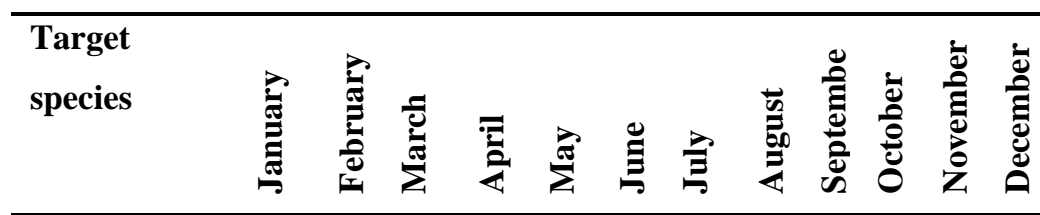

\begin{tabular}{ll}
\hline Mullus spp. & (Relini et al., 1999; Voliani, 1999; Sieli et \\
& al., 2011) \\
$\begin{array}{l}\text { Merluccius } \\
\text { merluccius } \\
\text { Nephrops } \\
\text { norvegicus }\end{array}$ & (Martin et al., 1999; Domínguez-Petit, \\
Aristeus & $2008)$ \\
antennatus & (Sarda, 1991) \\
\hline
\end{tabular}

574 Table 2: Temporal/seasonal closures of trawling fisheries in Dénia and La Vila Joiosa ports during the 575 studied 10 years (2002-2011). Shaded years were used in the analysis of variance (ANOVA).

\begin{tabular}{cccccccccccc}
\hline Year & $\mathbf{2 0 0 2}$ & $\mathbf{2 0 0 3}$ & $\mathbf{2 0 0 4}$ & $\mathbf{2 0 0 5}$ & $\mathbf{2 0 0 6}$ & $\mathbf{2 0 0 7}$ & $\mathbf{2 0 0 8}$ & $\mathbf{2 0 0 9}$ & $\mathbf{2 0 1 0}$ & $\mathbf{2 0 1 1}$ \\
\hline Dénia & June & June & Sep. & June & Sep. & Sep. & $15^{\text {th }}$ & Sep. to $15^{\text {th }}$ & June & Sep. & $\begin{array}{l}15^{\text {th }} \text { Jan. to } 15^{\text {th }} \text { Feb }+ \\
\text { Oct. }\end{array}$ \\
La Vila & May & May & June & May & June & June & June & Jan. & June & Sep. \\
Joiosa & & & & & & & & & & \\
\hline
\end{tabular}


578 Table 3: Number of samples and levels per factor used in analysis of variance (ANOVA). Dash (-)

579 indicates that the factor was not used in the analysis, because of the lack of data to balance the model.

\begin{tabular}{|c|c|c|c|c|c|c|}
\hline \multicolumn{2}{|c|}{ The analysis } & \multicolumn{3}{|c|}{ Levels per factor } & \multicolumn{2}{|c|}{ Number of Samples } \\
\hline \multirow{5}{*}{ 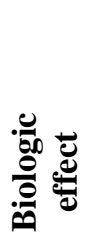 } & Métier & Closure & $\begin{array}{l}\text { Season or } \\
\text { Port }\end{array}$ & Year & Random samples per level & Total samples \\
\hline & Red mullet & 2 & 2 & - & 9 & 36 \\
\hline & European hake & 2 & 2 & 3 & 24 & 288 \\
\hline & Norway lobster & 2 & 2 & 3 & 3 & 36 \\
\hline & Red shrimp & 2 & 2 & 5 & 29 & 580 \\
\hline \multirow{4}{*}{ 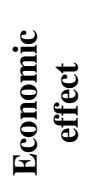 } & Red mullet & 2 & 2 & - & 10 & 40 \\
\hline & European hake & 2 & 2 & 3 & 24 & 288 \\
\hline & Norway lobster & 2 & 2 & 4 & 3 & 48 \\
\hline & Red shrimp & 2 & 2 & 5 & 29 & 580 \\
\hline \multirow{4}{*}{ 离 } & Red mullet & 3 & 2 & 3 & 4 & 72 \\
\hline & European hake & 3 & 2 & 2 & 25 & 300 \\
\hline & Norway lobster & 3 & 2 & 2 & 3 & 36 \\
\hline & Red shrimp & 3 & 2 & 5 & 38 & 1140 \\
\hline
\end{tabular}

580

581

582 
583 Table 4: Analysis of deviance table for generalized linear models (GLMs) fitted to total CPUE and target

584 species CPUE for the four métiers (from 2002 to 2011) in Dénia and La Vila Joiosa. Df.: degrees of

585 freedom; Res. Df.: residual of degree of freedom; Resid. Dev.: residual deviance; Dev. ex (\%): deviance

586 explained; F: F value. Factors are arranged according to the percentage of explained deviance.

\begin{tabular}{|c|c|c|c|c|c|c|c|}
\hline Métier & Model & Df. & Deviance & Res. Df. & Resid. Dev & Dev. ex (\%) & $\mathbf{F}$ \\
\hline \multirow{14}{*}{ 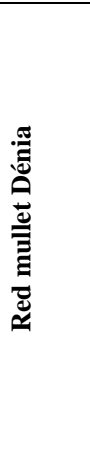 } & Total CPUE & & & & & $27.51 \%$ & \\
\hline & NULL & & & 15422 & 3868.448 & & \\
\hline & Vessel & 61 & 599.9565 & 15339 & 2804.116 & $15.51 \%$ & $53.80108 * * *$ \\
\hline & Month & 11 & 162.6728 & 15402 & 3551.041 & $4.21 \%$ & $80.89528 * * *$ \\
\hline & Year & 9 & 154.7339 & 15413 & 3713.714 & $4.00 \%$ & $94.04682 * * *$ \\
\hline & $\mathrm{TL}$ & 1 & 132.1933 & 15401 & 3418.848 & $3.42 \%$ & $723.1202^{* * * *}$ \\
\hline & GT & 1 & 14.77506 & 15400 & 3404.073 & $0.38 \%$ & $80.82214 * * *$ \\
\hline & Mullus spp. C & & & & & $30.99 \%$ & \\
\hline & NULL & & & 15422 & 14912.12 & & \\
\hline & Month & 11 & 2104.157 & 15402 & 12270.94 & $14.11 \%$ & $285.1197 * * *$ \\
\hline & Vessel & 61 & 1263.461 & 15339 & 10290.94 & $8.47 \%$ & $30.87265 * * *$ \\
\hline & Year & 9 & 537.0255 & 15413 & 14375.1 & $3.60 \%$ & $88.93942 * * *$ \\
\hline & GT & 1 & 437.5996 & 15400 & 11554.4 & $2.93 \%$ & $652.2571 * * *$ \\
\hline & $\mathrm{TL}$ & 1 & 278.9381 & 15401 & 11992 & $1.87 \%$ & $415.7668 * * *$ \\
\hline \multirow{14}{*}{ 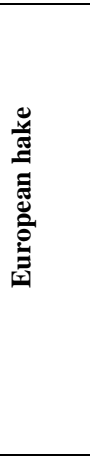 } & Total CPUE & & & & & $34.63 \%$ & \\
\hline & NULL & & & 42528 & 9099.015 & & \\
\hline & Vessel & 75 & 1188.273 & 42431 & 5948.143 & $13.06 \%$ & $113.0204 * * *$ \\
\hline & Year & 9 & 1038.993 & 42519 & 8060.022 & $11.42 \%$ & 823.5158 *** \\
\hline & $\mathrm{TL}$ & 1 & 755.4386 & 42507 & 7168.982 & $8.30 \%$ & 5388.911 *** \\
\hline & Month & 11 & 135.6011 & 42508 & 7924.42 & $1.49 \%$ & $87.93717 * * *$ \\
\hline & GT & 1 & 32.56546 & 42506 & 7136.416 & $0.36 \%$ & $232.3052 * * *$ \\
\hline & M. merlucciu & & & & & $55.20 \%$ & \\
\hline & NULL & & & 42528 & 30597.13 & & \\
\hline & Vessel & 75 & 11718.92 & 42431 & 13707.77 & $38.30 \%$ & $483.6629 * * *$ \\
\hline & $\mathrm{TL}$ & 1 & 3104.386 & 42507 & 25690.29 & $10.15 \%$ & $9609.309 * * *$ \\
\hline & Year & 9 & 987.8003 & 42519 & 29609.33 & $3.23 \%$ & $339.7372 * * *$ \\
\hline & Month & 11 & 814.6563 & 42508 & 28794.67 & $2.66 \%$ & $229.2441 * * *$ \\
\hline & GT & 1 & 263.5967 & 42506 & 25426.69 & $0.86 \%$ & $815.9365^{* * *}$ \\
\hline \multirow{11}{*}{ 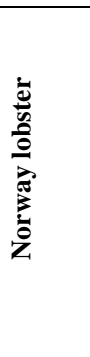 } & Total CPUE & & & & & $45.10 \%$ & \\
\hline & $\overline{\text { NULL }}$ & & & 5151 & 4481.877 & & \\
\hline & Vessel & 56 & 1190.241 & 5075 & 2460.75 & $26.56 \%$ & $43.83444 * * *$ \\
\hline & Year & 9 & 701.9692 & 5142 & 3779.908 & $15.66 \%$ & $160.8585^{* * *}$ \\
\hline & Month & 11 & 128.9173 & 5131 & 3650.991 & $2.88 \%$ & $24.17058^{* * * *}$ \\
\hline & N. norvegicu. & & & & & $31.35 \%$ & \\
\hline & NULL & $\overline{N A}$ & NA & 5151 & 4027.901 & & \\
\hline & Vessel & 56 & 716.9815 & 5074 & 2765.098 & $17.80 \%$ & $23.49416^{* * * *}$ \\
\hline & Year & 9 & 262.459 & 5142 & 3765.442 & $6.52 \%$ & $53.51295^{* * * *}$ \\
\hline & Month & 11 & 208.4196 & 5131 & 3557.023 & $5.17 \%$ & $34.76848 * * *$ \\
\hline & TL & 1 & 74.94319 & 5130 & 3482.079 & $1.86 \%$ & $137.522^{* * * *}$ \\
\hline \multirow{13}{*}{ 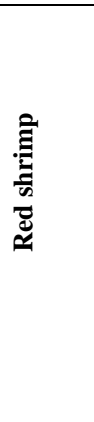 } & Total CPUE & & & & & $33.70 \%$ & \\
\hline & NULL & & & 26798 & 14815.38 & & \\
\hline & Vessel & 56 & 3021.415 & 26720 & 9822.623 & $20.39 \%$ & $146.768 * * *$ \\
\hline & TL & 1 & 1241.442 & 26777 & 13327.09 & $8.38 \%$ & $3377.034 * * *$ \\
\hline & GT & 1 & 483.0545 & 26776 & 12844.04 & $3.26 \%$ & $1314.029 * * *$ \\
\hline & Year & 9 & 162.7068 & 26789 & 14652.68 & $1.10 \%$ & $49.17816^{* * * *}$ \\
\hline & Month & 11 & 84.14181 & 26778 & 14568.53 & $0.57 \%$ & $20.8079 * * *$ \\
\hline & A. antennatus & & & & & $23.07 \%$ & \\
\hline & NULL & & & 26798 & 13600.61 & & \\
\hline & Vessel & 56 & 1770.153 & 26721 & 10462.11 & $13.02 \%$ & $80.73395^{* * *}$ \\
\hline & GT & 1 & 741.8277 & 26777 & 12232.27 & $5.45 \%$ & $1894.682 * * *$ \\
\hline & Year & 9 & 383.5055 & 26789 & 13217.1 & $2.82 \%$ & $108.8335^{* * *}$ \\
\hline & Month & 11 & 243.0086 & 26778 & 12974.09 & $1.79 \%$ & $56.42379 * * *$ \\
\hline
\end{tabular}


Table 5. Results of analysis of variance (ANOVA) with 2 factors (C: closure; S: season) for biologic effect (the total CPUE of Red mullet métier and Mullus spp. CPUE). With 2 factors (C: closure; P: port) for economic effect (price at home/closed port) and with 3 factors (C: closure; P: port; Yr: year) for price at neighbour/open port. Df: degrees of freedom; MS: mean square; F: F value. Levels of significance were $* \mathrm{p}<0.05$, ** $<0.01$ and $* * * \mathrm{p}<0.001$. Dash $(-)$ indicates that there is no transformation. (a) indicates that there is no homogeneity of variance, the levels of significance being $* p<0.01$; $* * p<0.001$.

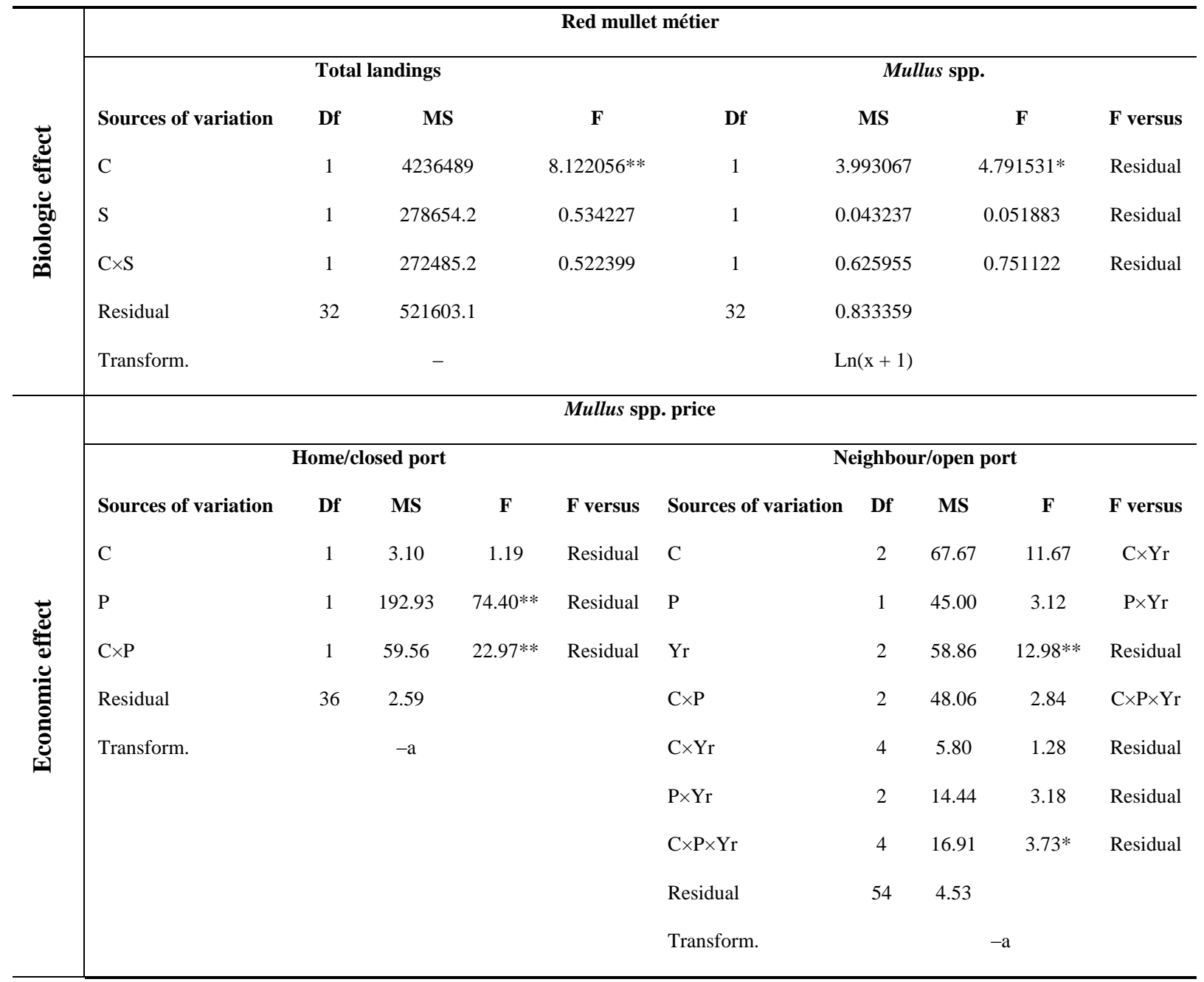


596 Table 6. Analysis of variance (ANOVA) results with 3 factors (C: closure; S: season; Yr: year) for 597 biologic effect (total CPUE by métier and target species CPUE), and with 3 factors (C: closure; P: port; 598 Yr: year) for economic effect (the first sale price at home/closed and neighbour/open ports) of the target 599 species Merluccius merluccius, Nephrops norvegicus and Aristeus antennatus. Df: degrees of freedom; 600 MS: mean square; F: F value. Levels of significance were *p $<0.05$, **p $<0.01$ and $* * * p<0.001$. Dash $(-)$ 601 indicates that there is no transformation. (a) indicates that there is no homogeneity of variance, the levels 602 of significance being *p $<0.01 ; * * \mathrm{p}<0.001$

603

604 


\begin{tabular}{|c|c|c|c|c|c|c|c|c|c|c|c|c|c|c|c|c|c|c|c|c|}
\hline \multirow{12}{*}{ 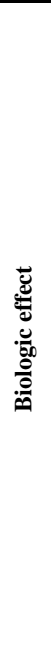 } & Sources of & \multicolumn{6}{|c|}{ European hake métier } & \multicolumn{6}{|c|}{ Norway lobster métier } & \multicolumn{6}{|c|}{ Red shrimp métier } & \multirow[t]{3}{*}{$F$ versus } \\
\hline & \multirow[t]{2}{*}{ variation } & \multicolumn{3}{|c|}{ Total landings } & \multicolumn{3}{|c|}{ Merluccius merluccius } & \multicolumn{3}{|c|}{ Total landings } & \multicolumn{3}{|c|}{ Nephrops norvegicus } & \multicolumn{3}{|c|}{ Total landings } & \multicolumn{3}{|c|}{ Aristeus antennatus } & \\
\hline & & Df & MS & $\mathbf{F}$ & Df & MS & $\mathbf{F}$ & Df & MS & $\mathbf{F}$ & Df & MS & $\mathbf{F}$ & Df & MS & $\mathbf{F}$ & Df & MS & $\mathbf{F}$ & \\
\hline & C & 1 & 327799512.4 & 4.925897 & 1 & 50.08891 & 0.751939 & 1 & 92.68107 & 20.35351* & 1 & 58.1988 & 4.856206 & 1 & 13715694 & 4.852378 & 1 & 657.3687 & $28.24121 *$ & $\mathrm{C} \times \mathrm{Yr}$ \\
\hline & $\mathbf{S}$ & 1 & 659835431.1 & 5.369455 & 1 & 37.84119 & 0.341613 & 1 & 66.03758 & 4.353176 & 1 & 46.17448 & 6.303008 & 1 & 14269001 & 4.643219 & 1 & 3006.823 & 3.209321 & $\mathrm{~S} \times \mathrm{Yr}$ \\
\hline & $\mathbf{Y r}$ & 2 & 760896305.1 & $17.91913^{* *}$ & 2 & 35.06301 & 3.524418 & 2 & 52.91542 & 2.726493 & 2 & 21.64308 & 2.114817 & 4 & 2084831 & 2.126182 & 4 & 532.1095 & $5.057912 * *$ & Residual \\
\hline & $\mathrm{C} \times \mathrm{S}$ & 1 & 15482530.58 & 0.360144 & 1 & 4.785256 & 0.24667 & 1 & 0.194997 & 0.073356 & 1 & 39.74125 & 6.18646 & 1 & 14708996 & 48.42887* & 1 & 717.1961 & 2.13177 & $\mathrm{C} \times \mathrm{S} \times \mathrm{Yr}$ \\
\hline & $\mathrm{C} \times \mathrm{Yr}$ & 2 & 66546154.89 & 1.567164 & 2 & 66.61301 & $6.695721^{*}$ & 2 & 4.553567 & 0.234625 & 2 & 11.98442 & 1.171037 & 4 & 2826592 & 2.882655 & 4 & 23.27693 & 0.221256 & Residual \\
\hline & $\mathbf{S} \times \mathbf{Y r}$ & 2 & 122886843.9 & 2.89399 & 2 & 110.772 & $11.13444 * *$ & 2 & 15.16998 & 0.78164 & 2 & 7.325785 & 0.715827 & 4 & 3073084 & 3.134036 & 4 & 936.9032 & $8.905637 * *$ & Residual \\
\hline & $\mathbf{C} \times \mathbf{S} \times \mathbf{Y r}$ & 2 & 42989851.74 & 1.012413 & 2 & 19.39944 & 1.949968 & 2 & 2.658219 & 0.136966 & 2 & 6.423908 & 0.627702 & 4 & 303723.7 & 0.309748 & 4 & 336.4322 & 3.197922 & Residual \\
\hline & Residual & 276 & 42462781.24 & & 276 & 9.948594 & & 24 & 19.40787 & & 24 & 10.23402 & & 560 & 980551.5 & & 560 & 105.2034 & & \\
\hline & Transform. & & & & & & -a & & & & & & & & & & & & a & \\
\hline \multirow{12}{*}{ 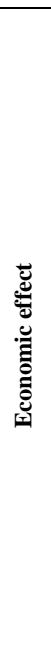 } & Sources of & \multicolumn{6}{|c|}{ Merluccius merluccius price } & \multicolumn{6}{|c|}{ Nephrops norvegicus price } & \multicolumn{6}{|c|}{ Aristeus antennatus price } & F versus \\
\hline & variation & \multicolumn{3}{|c|}{ Home/closed port } & \multicolumn{3}{|c|}{ Neighbour/open port } & \multicolumn{3}{|c|}{ Home/closed port } & \multicolumn{3}{|c|}{ Neighbour/open port } & \multicolumn{3}{|c|}{ Home/closed port } & \multicolumn{3}{|c|}{ Neighbour/open port } & \\
\hline & & Df & MS & $\mathbf{F}$ & Df & MS & $\mathbf{F}$ & Df & MS & $\mathbf{F}$ & Df & MS & $\mathbf{F}$ & Df & MS & $\mathbf{F}$ & Df & MS & $\mathbf{F}$ & \\
\hline & $\mathbf{C}$ & 1 & 96.45 & 3.20 & 2 & 84.87 & 89.51 & 1 & 4.82 & 0.01 & 2 & 4.05 & 0.04 & 1 & 6335.52 & 4.67 & 2 & 7326.20 & 8.48 & $\mathrm{C} \times \mathrm{Yr}$ \\
\hline & $\mathbf{P}$ & 1 & 6.22 & 0.22 & 1 & 213.03 & 41.42 & 1 & 103.02 & 1.79 & 1 & 831.44 & 9.52 & 1 & 69405.43 & $34.59^{*}$ & 1 & 107541.92 & $21.71^{*}$ & $\mathrm{P} \times \mathrm{Yr}$ \\
\hline & $\mathbf{Y r}$ & 2 & 89.51 & $23.54 * *$ & 1 & 207.34 & 30.15 & 3 & 824.02 & $14.55^{* * * *}$ & 1 & 1539.35 & $15.77 * * *$ & 4 & 982.10 & $5.13 * *$ & 4 & 2796.53 & $10.15^{* *}$ & Residual \\
\hline & $\mathbf{C} \times \mathbf{P}$ & 1 & 41.42 & 16.00 & 2 & 10.03 & 27.79 & 1 & 48.87 & 0.16 & 2 & 53.64 & 0.17 & 1 & 15113.25 & $23.56^{*}$ & 2 & 11666.11 & $10.66 *$ & $\mathrm{C} \times \mathrm{P} \times \mathrm{Yr}$ \\
\hline & $\mathrm{C} \times \mathrm{Yr}$ & 2 & 30.15 & $7.93 * *$ & 2 & 19.72 & 89.51 & 3 & 349.46 & $6.17 * *$ & 2 & 92.19 & 0.94 & 4 & 1356.09 & $7.08^{* * *}$ & 8 & 863.44 & $3.13^{*}$ & Residual \\
\hline & $\mathbf{P} \times \mathbf{Y r}$ & 2 & 27.79 & $7.31 * *$ & 1 & 313.37 & 41.42 & 3 & 57.56 & 1.02 & 1 & 87.32 & 0.89 & 4 & 2006.75 & $10.48^{* *}$ & 4 & 4952.58 & $17.98 * *$ & Residual \\
\hline & $\mathbf{C} \times \mathbf{P} \times \mathbf{Y r}$ & 2 & 2.59 & 0.68 & 2 & 19.78 & 30.15 & 3 & 306.03 & $5.40 * *$ & 2 & 308.15 & 3.16 & 4 & 641.51 & 3.35 & 8 & 1094.36 & $3.97 * *$ & Residual \\
\hline & Residual & 276 & 3.80 & & 288 & 4.83 & 27.79 & 32 & 56.64 & & 24 & 97.63 & & 560 & 191.47 & & 1110 & 275.45 & & \\
\hline & Transform. & \multicolumn{3}{|c|}{$-\mathrm{a}$} & \multicolumn{3}{|c|}{$-\mathrm{a}$} & \multicolumn{3}{|c|}{ - } & \multicolumn{3}{|c|}{ - } & \multicolumn{3}{|c|}{$-\mathrm{a}$} & & & a & \\
\hline
\end{tabular}




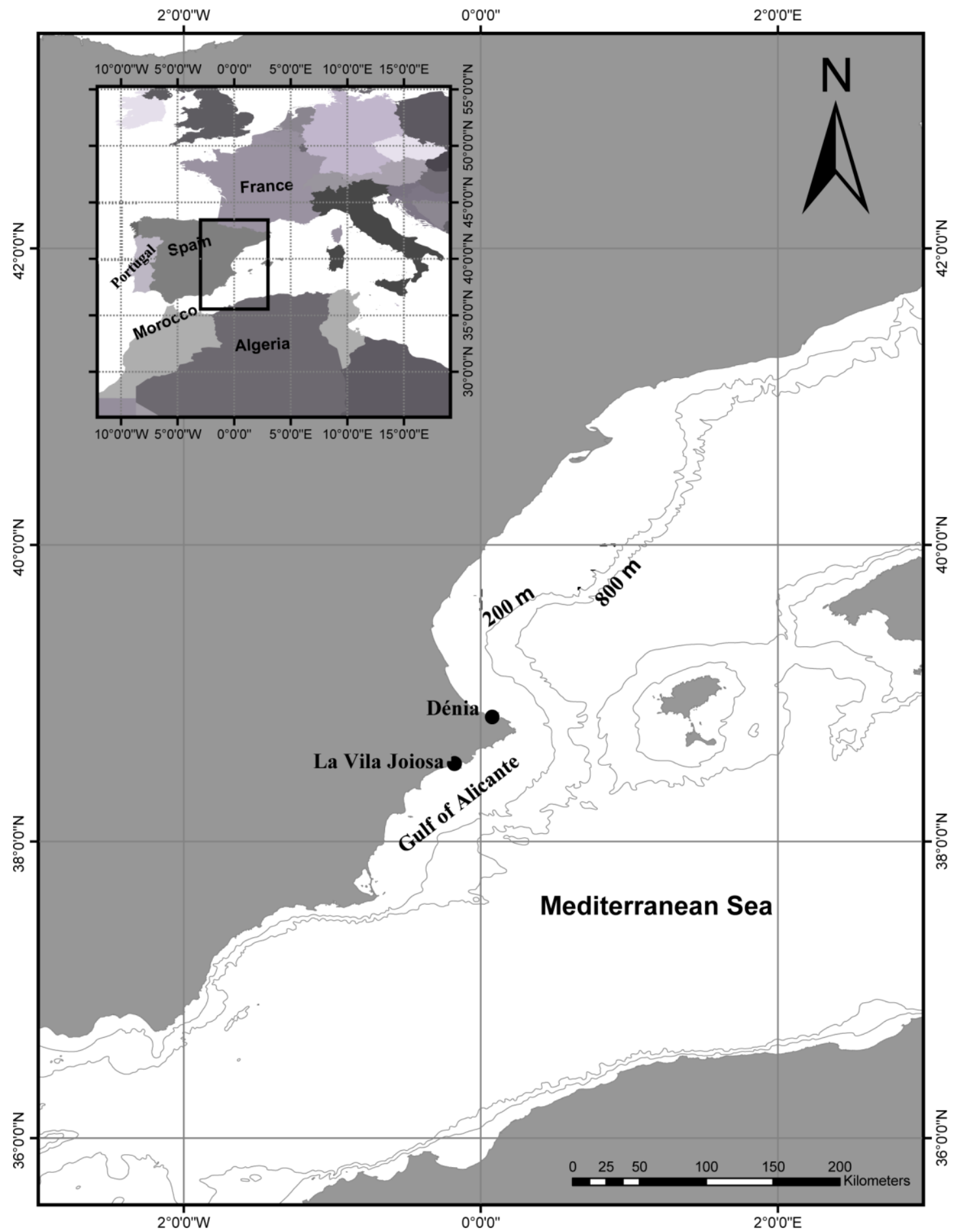

609 Figure 1: Map of the study area (SW Mediterranean) showing the location of the two trawling ports La 610 Vila Joiosa and Dénia (Spain). 
(A) Total Landings (kg)
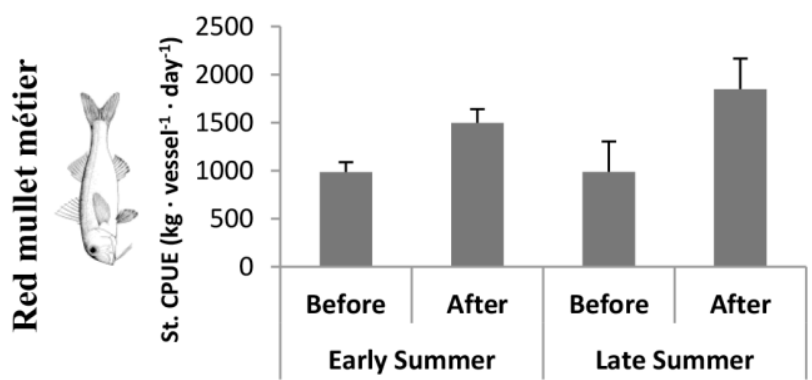

(C) Total Landings (kg)
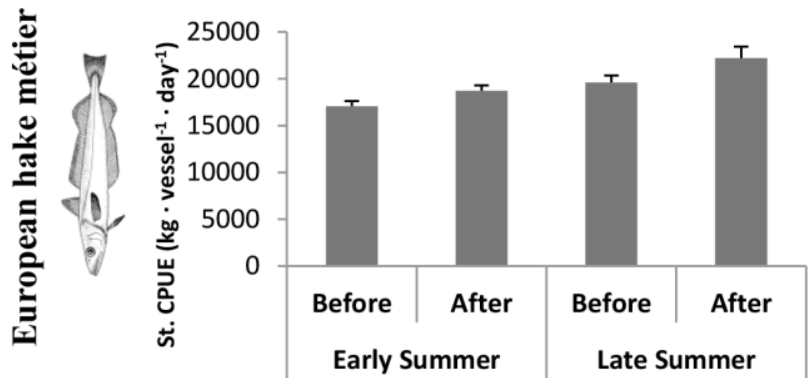

(E) Total Landings (kg)

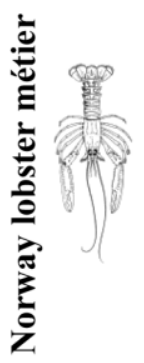

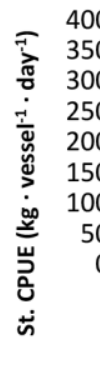

-
0
-
$0-$
$0-$
$0-$

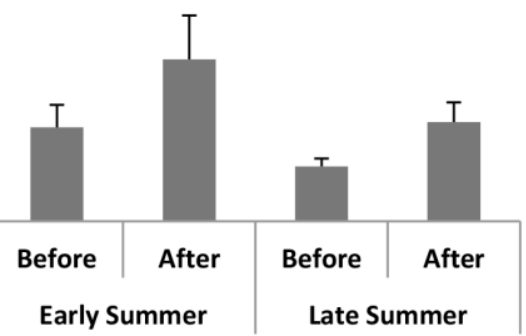

(G) Total Landings (kg)
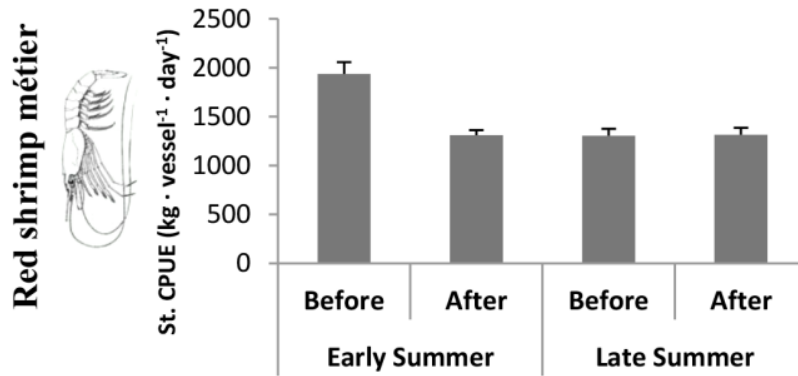

(B) Mullus spp. (kg)

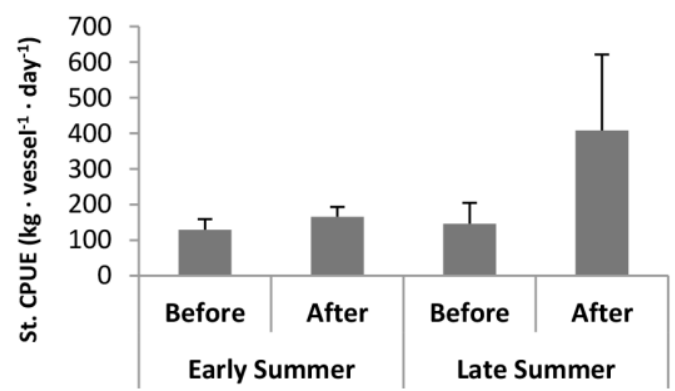

(D) Merluccius merluccius (kg)

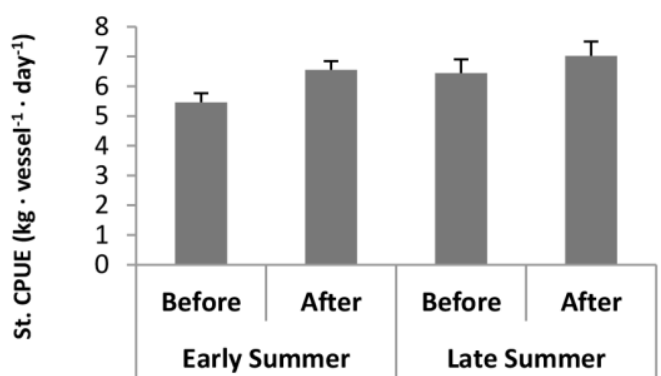

(F) Nephrops norvegicus (kg)

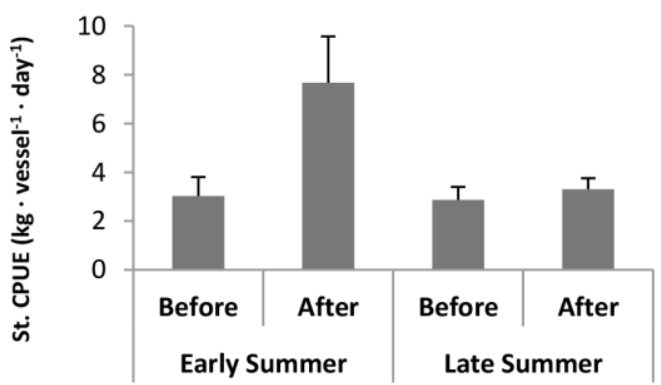

(H) Aristeus antennatus (kg)

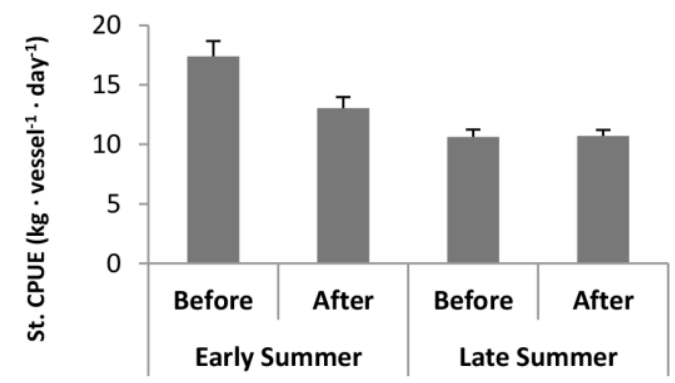

613 Figure 2: Mean CPUE ( $\mathrm{kg} \cdot$ vessel $^{-1} \cdot$ day $\left.^{-1}\right)$ and standard error of the total landings (left) of the four 614 métiers: (a) Red mullet, (c) European hake, (e) Norway lobster), and (g) Red shrimp, and target species 615 (right): (b) Mullus spp., (d) Merluccius merluccius, (f) Nephrops norvegicus and (h) Aristeus antennatus, during two seasons before and after the closure. 
(A)
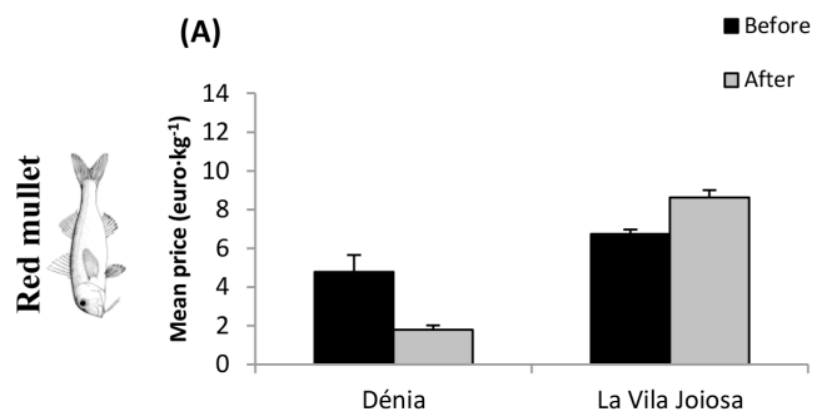

(C)
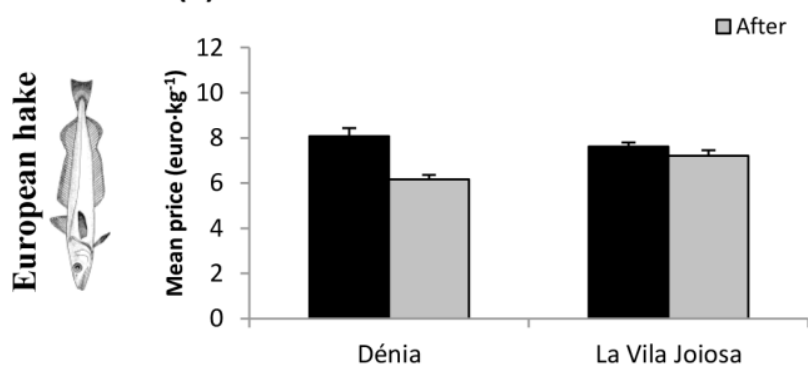

(E)
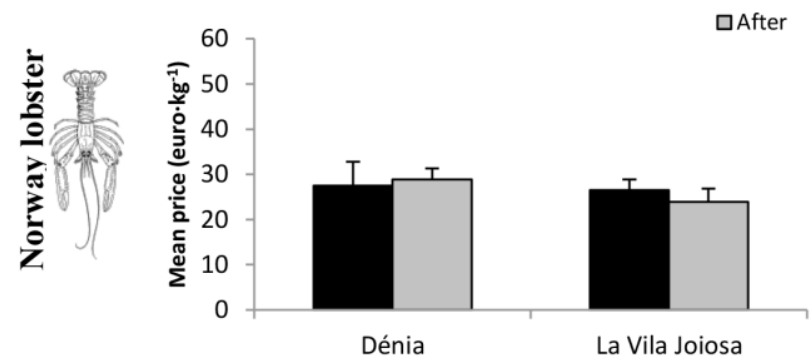

(G)
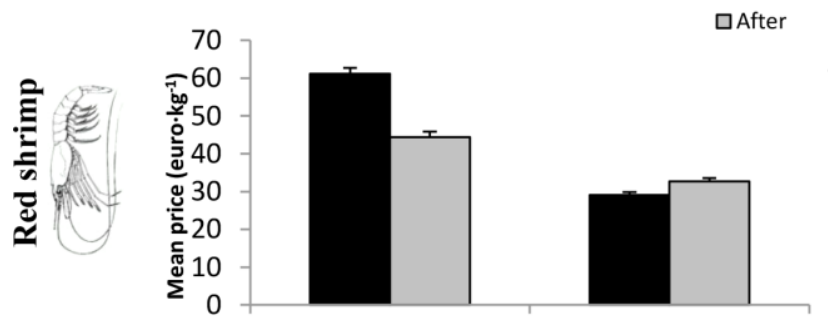

Dénia

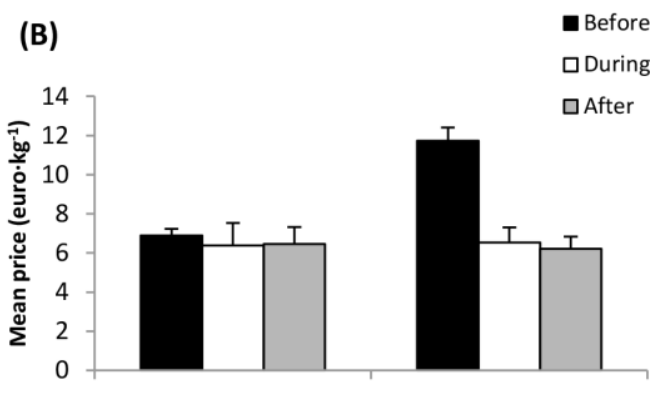

La Vila Joiosa
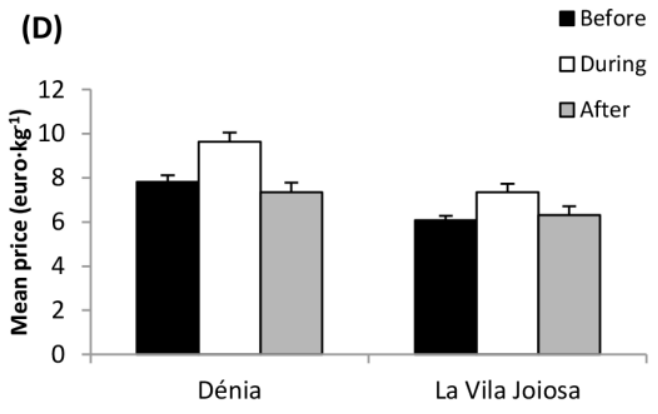

(F)

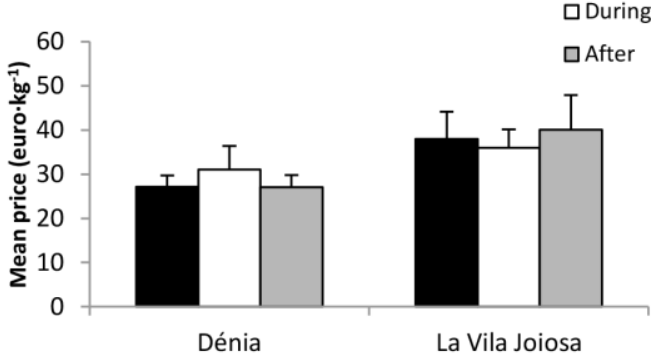

(H)

- Before 口During $\square$ After
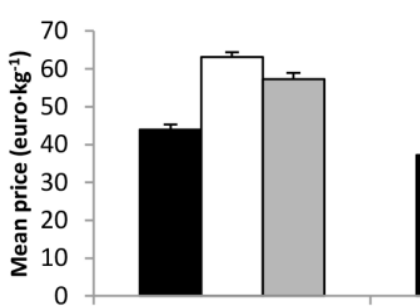

Dénia

Before $\square$ During After

La Vila Joiosa

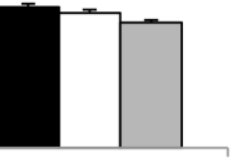

La Vila Joiosa

618 Figure 3: Mean first sale price (euro $\cdot \mathrm{kg}^{-1}$ ) and standard error of the main target species: (a,b) Mullus spp., (c,d) Merluccius merluccius, (e,f) Nephrops norvegicus and (g,h) Aristeus antennatus of the four métiers: Red mullet, European hake, Norway lobster, and Red shrimp in the two ports before and after the closure (left) and their mean prices at neighbour/open port before, during and after the closure (right). 


\section{Appendixes}

625 Appendix 1: Model selection procedure for the total CPUE and target species CPUE by métier shows the 626 last 5 values based on AIC: Akaike Information Criterion.

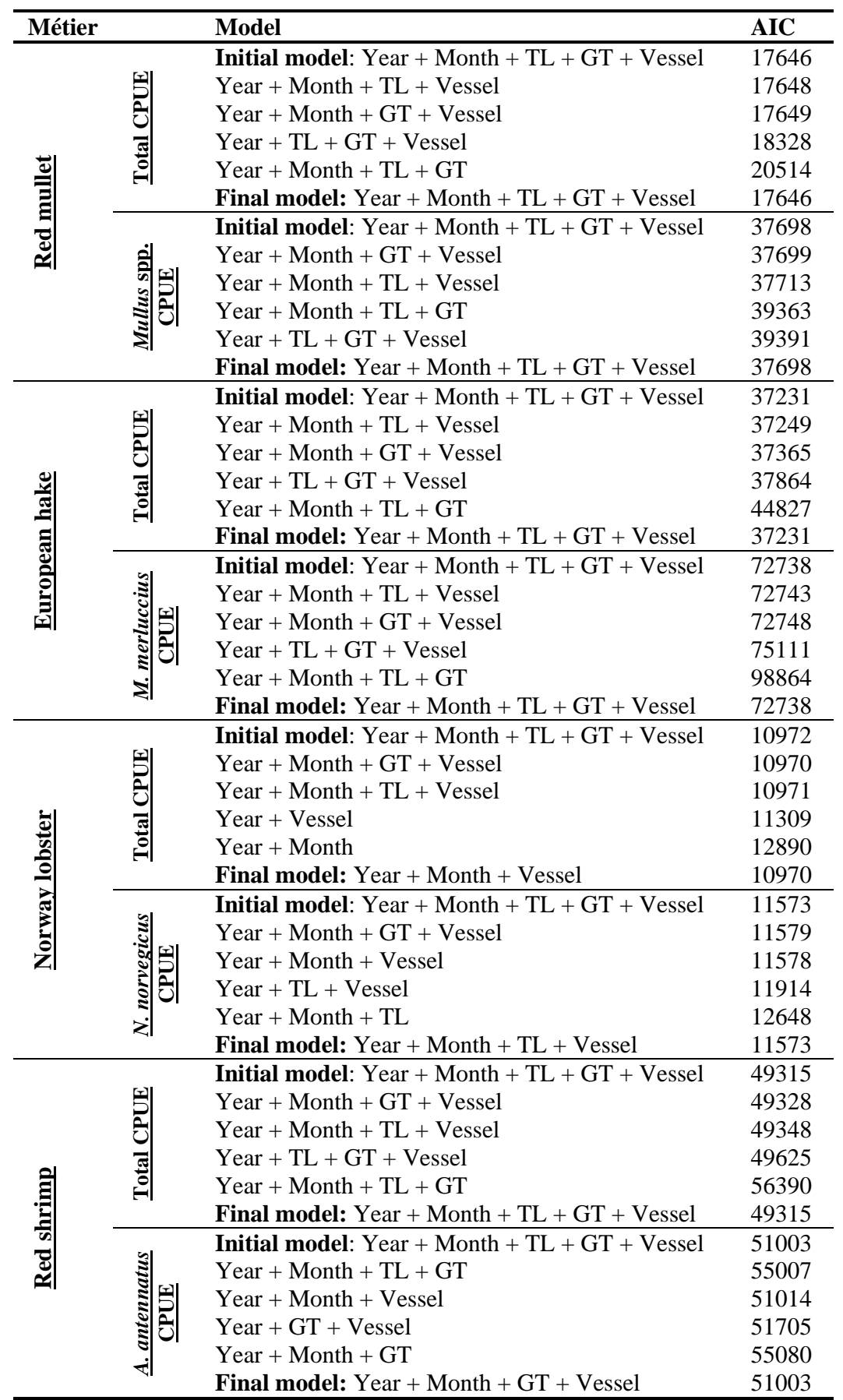


629 Appendix 2: Estimates and standard error from a generalized linear model fitted to total CPUE of Red 630 mullet, European hake, Norway lobster and Red shrimp métiers of the Dénia and La Vila Joiosa fleet 631 from 2002 to 2011, incorporating the main effects of year, month, individual vessel (V), total length (TL), 632 and gross tonnage (GT). Estimates express the difference between each level of the factors and the first 633 level.

\begin{tabular}{|c|c|c|c|c|c|c|c|c|c|c|c|}
\hline \multicolumn{4}{|c|}{ Red mullet } & \multicolumn{2}{|c|}{ European hake } & \multicolumn{4}{|c|}{ Norway lobster } & \multicolumn{2}{|c|}{ Red shrimp } \\
\hline & Estimate & St. Error & & Estimate & St. Error & & Estimate & St. Error & & Estimate & St. Error \\
\hline January-2002-V1* & 7.07186 & 0.597771 & January-2002-V1* & 9.656441 & 0.435352 & January-2002-V1* & 4.583586 & 0.080132 & January-2002-V1* & 7.073531 & 0.395798 \\
\hline 2003 & 0.11041 & 0.019005 & 2003 & -0.10942 & 0.007868 & 2003 & -0.1361 & 0.044144 & 2003 & -0.18371 & 0.017303 \\
\hline 2004 & 0.188618 & 0.017919 & 2004 & 0.004487 & 0.008064 & 2004 & -0.30599 & 0.054124 & 2004 & -0.12458 & 0.017152 \\
\hline 2005 & 0.165329 & 0.018309 & 2005 & 0.047184 & 0.007911 & 2005 & 0.002079 & 0.046501 & 2005 & -0.218 & 0.017578 \\
\hline 2006 & 0.22317 & 0.017956 & 2006 & 0.258221 & 0.008148 & 2006 & -0.09267 & 0.050718 & 2006 & -0.11897 & 0.017294 \\
\hline 2007 & 0.184024 & 0.017525 & 2007 & 0.243681 & 0.008434 & 2007 & 0.328391 & 0.060507 & 2007 & -0.03435 & 0.017792 \\
\hline 2008 & 0.110805 & 0.017831 & 2008 & 0.031407 & 0.008594 & 2008 & 0.572799 & 0.048904 & 2008 & -0.13975 & 0.018235 \\
\hline 2009 & 0.103101 & 0.0185 & 2009 & 0.184607 & 0.00881 & 2009 & 0.234122 & 0.052624 & 2009 & -0.16039 & 0.017928 \\
\hline 2010 & 0.022416 & 0.019279 & 2010 & 0.136223 & 0.008519 & 2010 & 0.281723 & 0.05344 & 2010 & -0.14668 & 0.018287 \\
\hline 2011 & 0.374201 & 0.019678 & 2011 & 0.410925 & 0.009123 & 2011 & 0.506367 & 0.054207 & 2011 & -0.0799 & 0.019372 \\
\hline February & -0.08205 & 0.020278 & February & -0.09036 & 0.008124 & February & 0.113957 & 0.046093 & February & -0.03558 & 0.018455 \\
\hline March & -0.06781 & 0.021225 & March & -0.08448 & 0.008164 & March & 0.084945 & 0.053479 & March & 0.021608 & 0.017793 \\
\hline April & 0.037185 & 0.016849 & April & -0.05975 & 0.00869 & April & 0.254477 & 0.04654 & April & -0.05787 & 0.017893 \\
\hline May & -0.0829 & 0.017445 & May & -0.06218 & 0.009141 & May & 0.1708 & 0.046284 & May & 0.055368 & 0.018204 \\
\hline June & -0.0611 & 0.020834 & June & 0.014633 & 0.010209 & June & 0.349405 & 0.049657 & June & 0.034456 & 0.021124 \\
\hline July & 0.021947 & 0.018546 & July & 0.006692 & 0.008838 & July & 0.327895 & 0.044193 & July & 0.099216 & 0.018895 \\
\hline August & 0.032735 & 0.017907 & August & -0.00352 & 0.008079 & August & 0.027462 & 0.044215 & August & 0.035249 & 0.017518 \\
\hline September & 0.131632 & 0.019016 & September & 0.042824 & 0.008593 & September & -0.04956 & 0.055186 & September & 0.054111 & 0.019004 \\
\hline October & 0.237714 & 0.015883 & October & 0.05409 & 0.009302 & October & -0.04608 & 0.056719 & October & -0.06315 & 0.01814 \\
\hline November & 0.152178 & 0.015527 & November & 0.022037 & 0.009021 & November & -0.24841 & 0.051445 & November & -0.12019 & 0.017893 \\
\hline December & 0.055481 & 0.016306 & December & -0.00184 & 0.008779 & December & -0.30529 & 0.050957 & December & -0.12059 & 0.018102 \\
\hline TL & -0.04911 & 0.021058 & TL & -0.16576 & 0.014223 & V2 & -0.72323 & 0.115607 & TL & -0.05197 & 0.013348 \\
\hline GT & -0.01083 & 0.005465 & GT & -0.00766 & 0.001697 & V3 & 0.479193 & 0.407798 & GT & -0.0202 & 0.003404 \\
\hline V2 & -1.57139 & 0.23523 & V2 & -1.96404 & 0.155031 & V4 & 0.804949 & 0.080595 & V2 & -1.54997 & 0.149858 \\
\hline V3 & -0.2918 & 0.12924 & V3 & -0.37175 & 0.054455 & V5 & -0.05182 & 0.092091 & V3 & 0.043625 & 0.354714 \\
\hline V4 & 0.518885 & 0.166694 & V4 & 0.530009 & 0.034652 & V6 & 0.086776 & 0.099816 & V4 & 0.86607 & 0.059888 \\
\hline V5 & -0.07767 & 0.116677 & V5 & -0.10206 & 0.042458 & V7 & 0.28841 & 0.078119 & v5 & 0.440276 & 0.608196 \\
\hline V6 & -0.87758 & 0.190455 & V6 & -1.06699 & 0.116481 & V8 & -0.30065 & 0.091154 & V6 & -1.95054 & 0.213197 \\
\hline V7 & -0.38938 & 0.148548 & V7 & 0.547366 & 0.066859 & V9 & -0.04491 & 0.086092 & V7 & 0.761746 & 0.109067 \\
\hline V8 & -1.13945 & 0.273733 & V8 & -0.48568 & 0.038752 & V10 & 0.25803 & 0.09587 & V8 & 0.004159 & 0.046264 \\
\hline V9 & -0.21623 & 0.194094 & V9 & -0.61766 & 0.075482 & V11 & -0.79281 & 0.157082 & V9 & -0.27647 & 0.070419 \\
\hline V10 & -0.22052 & 0.192962 & V10 & -1.77034 & 0.16529 & V12 & 0.482046 & 0.118198 & V10 & -0.95527 & 0.189903 \\
\hline V11 & -0.53138 & 0.184921 & V11 & -0.81107 & 0.114278 & V13 & 0.13246 & 0.102262 & V11 & 1.256998 & 0.160018 \\
\hline V12 & -0.45926 & 0.198441 & V12 & -0.68281 & 0.056551 & V14 & 0.733662 & 0.082465 & V12 & -1.04204 & 0.103741 \\
\hline V13 & -1.09132 & 0.215168 & V13 & -1.18217 & 0.121598 & V15 & -0.26919 & 0.084838 & V13 & 2.112681 & 0.223202 \\
\hline V14 & -0.72699 & 0.226572 & V14 & -1.27904 & 0.125781 & V16 & -0.26477 & 0.320924 & V14 & 1.690243 & 0.121654 \\
\hline V15 & -0.66681 & 0.230722 & V15 & -1.39181 & 0.143216 & V17 & 0.852984 & 0.116207 & V15 & 1.039277 & 0.115888 \\
\hline V16 & -1.33402 & 0.26924 & V16 & -1.33913 & 0.131732 & V18 & 0.147011 & 0.122959 & V16 & -0.987 & 0.116383 \\
\hline V17 & 0.819366 & 0.388719 & V17 & 0.483063 & 0.109964 & V19 & 0.902686 & 0.09372 & V17 & 1.488695 & 0.133392 \\
\hline V18 & 0.251695 & 0.061339 & V18 & -0.48721 & 0.038473 & V20 & 0.707068 & 0.088267 & V18 & 0.851236 & 0.134201 \\
\hline V19 & -1.09913 & 0.18277 & V19 & -1.69404 & 0.16926 & V21 & -0.48127 & 0.136609 & V19 & 1.514216 & 0.161491 \\
\hline V20 & -0.48375 & 0.177021 & V20 & 0.985939 & 0.131471 & V22 & -0.20726 & 0.127817 & V20 & 0.840393 & 0.052312 \\
\hline V21 & 0.018231 & 0.101613 & V21 & 0.046496 & 0.022059 & V23 & -0.3557 & 0.097417 & V21 & -1.00018 & 0.085422 \\
\hline $\mathrm{V} 22$ & 0.679287 & 0.250559 & V22 & 0.095082 & 0.062088 & V24 & 0.605877 & 0.087908 & V22 & -0.06152 & 0.057306 \\
\hline $\mathrm{V} 23$ & -0.80884 & 0.251565 & V23 & -1.63471 & 0.114901 & V25 & -0.35975 & 0.497525 & V23 & 1.44478 & 0.611917 \\
\hline V24 & -0.66952 & 0.183124 & V24 & -1.01445 & 0.113656 & V26 & 0.171008 & 0.132799 & V24 & -0.63871 & 0.067384 \\
\hline $\mathrm{V} 25$ & -0.27065 & 0.16956 & V25 & 0.55535 & 0.090322 & V27 & 0.948124 & 0.087982 & V25 & 1.634847 & 0.178516 \\
\hline $\mathrm{V} 26$ & -0.28325 & 0.153137 & V26 & -0.42827 & 0.042428 & V28 & 0.318308 & 0.110422 & V26 & -1.05876 & 0.617841 \\
\hline V27 & -0.28739 & 0.130495 & V27 & -0.09379 & 0.109409 & V29 & 0.4662 & 0.087875 & V27 & 0.372172 & 0.112329 \\
\hline $\mathrm{V} 28$ & -0.38778 & 0.101666 & V28 & 0.522516 & 0.086609 & V30 & -0.58218 & 0.193222 & V28 & 1.643243 & 0.094761 \\
\hline V29 & -0.50807 & 0.182614 & V29 & 0.104598 & 0.065417 & V31 & 0.091512 & 0.111168 & V29 & 0.678454 & 0.086002 \\
\hline V30 & 0.388566 & 0.261588 & V30 & -1.87058 & 0.278836 & V32 & 0.421484 & 0.293377 & V30 & 0.157588 & 0.062676 \\
\hline V31 & -0.04113 & 0.451055 & V31 & -0.93315 & 0.107094 & V33 & 0.288668 & 0.11436 & V31 & 0.164221 & 0.077028 \\
\hline V32 & 0.545119 & 0.136497 & V32 & -0.896 & 0.105722 & V34 & 1.201244 & 0.086799 & V32 & 1.256126 & 0.151485 \\
\hline V33 & -0.17951 & 0.099361 & V33 & -0.54211 & 0.12665 & V35 & 0.608679 & 0.148629 & V33 & 0.005837 & 0.086438 \\
\hline V34 & -0.20054 & 0.437297 & V34 & -0.43874 & 0.066759 & V36 & 1.230548 & 0.082943 & V34 & 1.178933 & 0.115601 \\
\hline V35 & -0.2516 & 0.14805 & V35 & -0.35355 & 0.06445 & V37 & -0.06148 & 0.089036 & V35 & -0.13878 & 0.220789 \\
\hline V36 & -0.09997 & 0.132498 & V36 & -0.89542 & 0.070359 & V38 & 1.165579 & 0.410114 & V36 & 1.77149 & 0.195481 \\
\hline V37 & 0.913105 & 0.250251 & V37 & 0.650594 & 0.107705 & V39 & -0.31573 & 0.126535 & V37 & -0.85069 & 0.106028 \\
\hline V38 & 0.333546 & 0.150252 & V38 & -1.27258 & 0.128222 & V40 & -0.67725 & 0.318918 & V38 & -0.00864 & 0.43845 \\
\hline V39 & 0.307053 & 0.167149 & V39 & 0.01609 & 0.039679 & V41 & 0.930911 & 0.083781 & V39 & -0.29583 & 0.060816 \\
\hline V40 & 0.743139 & 0.360673 & V40 & 0.311523 & 0.083646 & V42 & 1.069781 & 0.084967 & V40 & -0.43337 & 0.076004 \\
\hline V41 & -0.51584 & 0.16156 & V41 & 0.620081 & 0.062955 & V43 & 0.867595 & 0.100415 & V41 & 0.726326 & 0.064763 \\
\hline V42 & -0.27608 & 0.152334 & V42 & -0.39947 & 0.043626 & V44 & 0.199618 & 0.084847 & V42 & 1.125085 & 0.113342 \\
\hline V43 & -1.10788 & 0.437453 & V43 & -0.43533 & 0.053201 & V45 & 0.756225 & 0.076999 & V43 & 1.310942 & 0.084165 \\
\hline V44 & 0.557192 & 0.139366 & V44 & -0.48607 & 0.103306 & V46 & 0.792661 & 0.102558 & V44 & 0.284848 & 0.054666 \\
\hline V45 & 0.763557 & 0.20421 & V45 & -0.41909 & 0.072557 & V47 & 0.853505 & 0.107746 & V45 & 1.201127 & 0.07482 \\
\hline
\end{tabular}




\begin{tabular}{|c|c|c|c|c|c|c|c|c|c|c|c|}
\hline $\mathrm{V} 46$ & 0.642105 & 0.172954 & V46 & 0.945093 & 0.084183 & V48 & -0.84843 & 0.276182 & V46 & 0.129186 & 0.133194 \\
\hline V47 & -0.87218 & 0.268715 & V47 & -0.09271 & 0.033032 & V49 & -0.10503 & 0.109945 & V47 & 1.827697 & 0.177322 \\
\hline V48 & 0.322836 & 0.116638 & V48 & 0.511912 & 0.063145 & V50 & 1.025268 & 0.089637 & V48 & -1.1529 & 0.165022 \\
\hline V49 & -0.27462 & 0.152432 & V49 & 0.374769 & 0.026801 & V51 & 0.463401 & 0.08647 & V49 & -0.31327 & 0.078544 \\
\hline V50 & -0.51516 & 0.168127 & V50 & 1.312256 & 0.110126 & V52 & -0.3356 & 0.118343 & V50 & 1.138536 & 0.061336 \\
\hline V51 & -0.99492 & 0.196588 & V51 & -1.03398 & 0.100716 & V53 & 0.20425 & 0.13186 & V51 & 0.123192 & 0.041013 \\
\hline V52 & -1.30585 & 0.315923 & V52 & -0.5112 & 0.082254 & V54 & -0.48609 & 0.173442 & V52 & -0.75423 & 0.059851 \\
\hline V53 & -0.56049 & 0.264419 & V53 & -1.69549 & 0.135213 & V55 & 0.147086 & 0.169926 & V53 & 0.167799 & 0.040687 \\
\hline V54 & -0.46262 & 0.152176 & V54 & -1.45223 & 0.375048 & V56 & 0.643779 & 0.088854 & V54 & -0.77274 & 0.095025 \\
\hline V55 & 0.490569 & 0.137507 & V55 & 0.514788 & 0.040571 & V57 & -0.36827 & 0.092285 & V55 & 2.071713 & 0.086552 \\
\hline V56 & -0.37812 & 0.431874 & V56 & 0.688723 & 0.056675 & & & & V56 & 2.176502 & 0.237638 \\
\hline V57 & -1.94661 & 0.308606 & V57 & 0.771957 & 0.069469 & & & & V57 & -0.25205 & 0.036005 \\
\hline V58 & -1.02301 & 0.228507 & V58 & -1.59961 & 0.157384 & & & & & & \\
\hline V59 & 0.278189 & 0.063655 & V59 & 0.150669 & 0.027856 & & & & & & \\
\hline V60 & 0.22543 & 0.118964 & V60 & 0.165525 & 0.036936 & & & & & & \\
\hline V61 & -0.28146 & 0.1554 & V61 & -1.00704 & 0.091645 & & & & & & \\
\hline \multirow[t]{15}{*}{ V62 } & 0.045715 & 0.126613 & V62 & 0.750018 & 0.124638 & & & & & & \\
\hline & & & V63 & -1.39794 & 0.108433 & & & & & & \\
\hline & & & V64 & -1.72434 & 0.126711 & & & & & & \\
\hline & & & V65 & -2.20744 & 0.194583 & & & & & & \\
\hline & & & V66 & -1.48205 & 0.173938 & & & & & & \\
\hline & & & V67 & -0.75184 & 0.060701 & & & & & & \\
\hline & & & V68 & 0.802976 & 0.040714 & & & & & & \\
\hline & & & V69 & 0.098312 & 0.035173 & & & & & & \\
\hline & & & V70 & -1.80874 & 0.116122 & & & & & & \\
\hline & & & V71 & 0.250967 & 0.084482 & & & & & & \\
\hline & & & V72 & 0.258796 & 0.02098 & & & & & & \\
\hline & & & V73 & 0.270801 & 0.020993 & & & & & & \\
\hline & & & V74 & 0.786141 & 0.147262 & & & & & & \\
\hline & & & V75 & -0.40915 & 0.078858 & & & & & & \\
\hline & & & V76 & -0.28025 & 0.058564 & & & & & & \\
\hline
\end{tabular}

634

635 
636 Appendix 3: Estimates and standard error from a generalized linear model fitted to CPUE of target

637 species Mullus spp., M. merluccius, N. norvegicus and A. antennatus of the Dénia and La Vila Joiosa fleet

638 from 2002 to 2011, incorporating the main effects of year, month, individual vessel (V), total length (TL),

639 and gross tonnage (GT). Estimates express the difference between each level of the factors and the first

640 level.

\begin{tabular}{|c|c|c|c|c|c|c|c|c|c|c|c|}
\hline \multicolumn{4}{|c|}{ Mullus spp. } & \multicolumn{2}{|c|}{ M. merluccius } & \multicolumn{4}{|c|}{$\begin{array}{l}\text { N. norvegicus } \\
\end{array}$} & \multicolumn{2}{|c|}{ A. antennatus } \\
\hline & Estimate & St. Error & & Estimate & St. Error & & Estimate & St. Error & & Estimate & St. Error \\
\hline January-2002-V1* & 4.515099 & 1.145155 & January-2002-V1* & 1.834713 & 0.660896 & January-2002-V1* & 0.625674 & 0.883577 & January-2002-V1* & 2.297945 & 0.241546 \\
\hline 2003 & -0.13074 & 0.036407 & 2003 & -0.30887 & 0.011945 & 2003 & -0.13843 & 0.047006 & 2003 & -0.12936 & 0.017709 \\
\hline 2004 & -0.27581 & 0.034327 & 2004 & -0.24841 & 0.012242 & 2004 & -0.45058 & 0.057454 & 2004 & -0.101 & 0.017555 \\
\hline 2005 & 0.006344 & 0.035075 & 2005 & -0.18408 & 0.01201 & 2005 & -0.30832 & 0.049493 & 2005 & -0.29461 & 0.018006 \\
\hline 2006 & 0.144605 & 0.034398 & 2006 & -0.02204 & 0.01237 & 2006 & -0.14682 & 0.053829 & 2006 & -0.12942 & 0.017729 \\
\hline 2007 & 0.20252 & 0.033573 & 2007 & -0.02368 & 0.012803 & 2007 & 0.111465 & 0.064328 & 2007 & -0.21702 & 0.018244 \\
\hline 2008 & 0.009779 & 0.034159 & 2008 & -0.23982 & 0.013047 & 2008 & 0.131691 & 0.052062 & 2008 & -0.30223 & 0.018727 \\
\hline 2009 & -0.0186 & 0.03544 & 2009 & 0.200179 & 0.013374 & 2009 & -0.02823 & 0.055955 & 2009 & -0.3481 & 0.018399 \\
\hline 2010 & -0.16323 & 0.036932 & 2010 & -0.10169 & 0.012932 & 2010 & 0.330465 & 0.05677 & 2010 & -0.05952 & 0.018778 \\
\hline 2011 & -0.03888 & 0.037698 & 2011 & 0.014736 & 0.013849 & 2011 & 0.165268 & 0.057595 & 2011 & -0.02636 & 0.019907 \\
\hline February & -0.29376 & 0.038847 & February & -0.10937 & 0.012333 & February & 0.156413 & 0.048873 & February & 0.144047 & 0.019046 \\
\hline March & 0.024265 & 0.040661 & March & -0.20013 & 0.012393 & March & 0.114625 & 0.056732 & March & 0.195499 & 0.018363 \\
\hline April & 0.286599 & 0.032278 & April & -0.22438 & 0.013192 & April & 0.422227 & 0.049343 & April & 0.264682 & 0.018465 \\
\hline May & 0.100915 & 0.03342 & May & -0.06233 & 0.013877 & May & 0.477009 & 0.049081 & May & 0.306592 & 0.018787 \\
\hline June & -0.07007 & 0.039911 & June & -0.01521 & 0.015498 & June & 0.69962 & 0.052658 & June & 0.121975 & 0.021792 \\
\hline July & 0.068638 & 0.035529 & July & 0.163511 & 0.013417 & July & 0.647806 & 0.046911 & July & 0.032719 & 0.0195 \\
\hline August & -0.234 & 0.034304 & August & 0.199645 & 0.012264 & August & 0.282978 & 0.046886 & August & -0.00048 & 0.018079 \\
\hline September & 0.137473 & 0.036429 & September & 0.153593 & 0.013044 & September & 0.283261 & 0.058518 & September & 0.138805 & 0.019611 \\
\hline October & 0.671113 & 0.030428 & October & 0.056566 & 0.014121 & October & 0.209951 & 0.060131 & October & 0.131308 & 0.01872 \\
\hline November & 0.60953 & 0.029746 & November & -0.02053 & 0.013694 & November & 0.313266 & 0.054561 & November & 0.025485 & 0.018464 \\
\hline December & 0.253553 & 0.031237 & December & -0.08417 & 0.013328 & December & 0.220973 & 0.054036 & December & -0.00292 & 0.018681 \\
\hline TL & 0.06528 & 0.040341 & TL & 0.076831 & 0.021592 & TL & 0.098632 & 0.037709 & GT & 0.012624 & 0.003511 \\
\hline GT & -0.04234 & 0.01047 & GT & 0.006937 & 0.002576 & V2 & 0.3378 & 0.315463 & V2 & 0.011267 & 0.110252 \\
\hline V2 & -1.34254 & 0.450632 & V2 & -0.40668 & 0.235348 & V3 & -0.63894 & 0.442882 & V3 & -0.56313 & 0.364222 \\
\hline V3 & -0.69709 & 0.247586 & V3 & 0.685464 & 0.082667 & V4 & 0.410432 & 0.085442 & V4 & 0.243027 & 0.061773 \\
\hline V4 & 0.988761 & 0.319338 & V4 & 0.252051 & 0.052605 & V5 & 0.411429 & 0.205556 & V5 & -1.81836 & 0.626918 \\
\hline V5 & -0.9095 & 0.223519 & v5 & 0.648178 & 0.064455 & V6 & -0.08022 & 0.1095 & V6 & -1.47724 & 0.208991 \\
\hline V6 & -1.32622 & 0.364856 & V6 & -0.46449 & 0.176827 & V7 & 0.443722 & 0.103737 & V7 & -0.09778 & 0.111635 \\
\hline V7 & -1.21496 & 0.284575 & V7 & -0.02604 & 0.101497 & V8 & -0.19837 & 0.09682 & v8 & -0.01898 & 0.042316 \\
\hline v8 & -1.39766 & 0.524392 & v8 & -0.33143 & 0.058828 & V9 & 0.515025 & 0.267519 & V9 & 0.456494 & 0.072669 \\
\hline V9 & -0.73455 & 0.371828 & V9 & 0.309991 & 0.114587 & V10 & -0.36593 & 0.121257 & V10 & -1.64822 & 0.171892 \\
\hline V10 & -1.62913 & 0.369659 & V10 & 0.295297 & 0.250922 & V11 & -0.64094 & 0.218027 & V11 & -0.29872 & 0.162402 \\
\hline V11 & -0.72953 & 0.354256 & V11 & 0.5011 & 0.173482 & V12 & 0.335415 & 0.141594 & V12 & 0.237644 & 0.0929 \\
\hline V12 & -0.76899 & 0.380156 & V12 & -0.60199 & 0.085849 & V13 & -0.07212 & 0.108811 & V13 & -0.41868 & 0.228137 \\
\hline V13 & -1.11483 & 0.412199 & V13 & 0.516281 & 0.184594 & V14 & 0.400988 & 0.087926 & V14 & -1.56083 & 0.125523 \\
\hline V14 & -1.1238 & 0.434046 & V14 & 0.241644 & 0.190945 & V15 & 0.168529 & 0.226396 & V15 & -0.34088 & 0.119597 \\
\hline V15 & -0.97548 & 0.441996 & V15 & -0.20976 & 0.217412 & V16 & 0.124958 & 0.390606 & V16 & 0.242676 & 0.097382 \\
\hline V16 & -2.76035 & 0.515786 & V16 & 0.176269 & 0.199979 & V17 & -0.15259 & 0.12951 & V17 & 0.138682 & 0.136287 \\
\hline V17 & 2.096412 & 0.744672 & V17 & -1.32703 & 0.166934 & V18 & -1.05623 & 0.149834 & V18 & -0.30069 & 0.134785 \\
\hline V18 & -0.6897 & 0.117508 & V18 & 0.441562 & 0.058404 & V19 & 0.514038 & 0.099959 & V19 & -0.46193 & 0.166653 \\
\hline V19 & -1.23826 & 0.350134 & V19 & -1.56549 & 0.25695 & V20 & 0.12624 & 0.113752 & V20 & 0.522748 & 0.047871 \\
\hline V20 & -0.83153 & 0.339122 & V20 & -0.00706 & 0.199583 & V21 & 0.334641 & 0.221302 & V21 & 0.189339 & 0.062403 \\
\hline V21 & 0.0088 & 0.194661 & V21 & -0.80817 & 0.033488 & V22 & -0.30048 & 0.14902 & V22 & -0.10336 & 0.0536 \\
\hline $\mathrm{V} 22$ & 0.953596 & 0.479998 & V22 & -0.58581 & 0.094255 & V23 & 0.14239 & 0.159957 & V23 & -1.70032 & 0.630886 \\
\hline V23 & -1.7592 & 0.481926 & V23 & -0.92837 & 0.174428 & V24 & -0.06634 & 0.097428 & V24 & -0.2589 & 0.053187 \\
\hline V24 & -1.50679 & 0.350813 & V24 & -0.97115 & 0.172538 & V25 & -1.33347 & 0.586484 & V25 & -0.00401 & 0.183463 \\
\hline V25 & -0.42173 & 0.324829 & V25 & -0.33077 & 0.137116 & V26 & 0.203269 & 0.157382 & V26 & -2.10677 & 0.630482 \\
\hline V26 & -1.01588 & 0.293365 & V26 & 0.160502 & 0.064408 & V27 & 0.778847 & 0.093397 & V27 & -0.40675 & 0.113958 \\
\hline V27 & -1.06238 & 0.249991 & V27 & -1.66893 & 0.166091 & V28 & -0.46396 & 0.133913 & V28 & 0.606904 & 0.097782 \\
\hline V28 & -0.93751 & 0.194763 & V28 & -0.60676 & 0.131479 & V29 & 0.33156 & 0.126101 & V29 & -0.00856 & 0.084614 \\
\hline V29 & -1.37123 & 0.349835 & V29 & -1.0938 & 0.099308 & V30 & -0.54293 & 0.206548 & V30 & 0.25744 & 0.056472 \\
\hline V30 & 0.732282 & 0.501126 & V30 & -2.42825 & 0.423294 & V31 & 0.471101 & 0.155244 & V31 & -0.28124 & 0.078526 \\
\hline V31 & -1.36178 & 0.86409 & V31 & 0.806884 & 0.162576 & V32 & -0.70412 & 0.319988 & V32 & -1.87865 & 0.151545 \\
\hline V32 & -0.25415 & 0.261489 & V32 & 0.083246 & 0.160493 & V33 & -0.06217 & 0.147741 & V33 & -0.34891 & 0.08415 \\
\hline V33 & -0.1983 & 0.190346 & V33 & -1.94454 & 0.192265 & V34 & 0.765027 & 0.09251 & V34 & 0.096324 & 0.1193 \\
\hline V34 & -2.62725 & 0.837733 & V34 & 0.376265 & 0.101345 & V35 & -0.55772 & 0.157602 & V35 & -0.27237 & 0.227855 \\
\hline V35 & -0.39935 & 0.283621 & V35 & -0.84198 & 0.097839 & V36 & 0.549602 & 0.094978 & V36 & -0.65221 & 0.200732 \\
\hline V36 & -1.00901 & 0.253828 & V36 & -0.87644 & 0.10681 & V37 & 0.432185 & 0.190888 & V37 & 0.367404 & 0.090272 \\
\hline V37 & 0.883375 & 0.479408 & V37 & -1.08662 & 0.163505 & V38 & -1.30583 & 0.451428 & V38 & -1.48019 & 0.45012 \\
\hline V38 & -0.4438 & 0.287838 & V38 & -0.96987 & 0.194651 & V39 & -0.36338 & 0.16132 & V39 & 0.374934 & 0.053216 \\
\hline V39 & -0.10611 & 0.32021 & V39 & -0.10118 & 0.060236 & V40 & -0.42712 & 0.338995 & V40 & 0.016997 & 0.078006 \\
\hline V40 & 1.974262 & 0.690944 & V40 & -0.36105 & 0.12698 & V41 & 0.173879 & 0.089092 & V41 & 0.243784 & 0.066676 \\
\hline
\end{tabular}




\begin{tabular}{|c|c|c|c|c|c|c|c|c|c|c|c|}
\hline V41 & -1.26363 & 0.309503 & V41 & -0.52115 & 0.09557 & V42 & 0.04269 & 0.090539 & V42 & -0.23448 & 0.116968 \\
\hline V42 & -0.90458 & 0.291828 & V42 & 0.351783 & 0.066227 & V43 & 0.361887 & 0.124511 & V43 & 0.484915 & 0.08274 \\
\hline V43 & -2.7202 & 0.838032 & V43 & 0.067142 & 0.080763 & V44 & -0.06015 & 0.090269 & V44 & -0.21198 & 0.056369 \\
\hline V44 & 0.81884 & 0.266984 & V44 & -1.19288 & 0.156826 & V45 & 0.506124 & 0.082124 & V45 & -0.23052 & 0.077212 \\
\hline V45 & 1.283742 & 0.391207 & V45 & -0.79459 & 0.110147 & V46 & 1.364734 & 0.243078 & V46 & -0.40477 & 0.111945 \\
\hline V46 & 1.150448 & 0.33133 & V46 & 0.408219 & 0.127796 & V47 & -0.6741 & 0.131163 & V47 & 0.298384 & 0.180544 \\
\hline V47 & -1.52084 & 0.514779 & V47 & 0.385046 & 0.050145 & V48 & -0.14342 & 0.336233 & V48 & -0.54432 & 0.157807 \\
\hline V48 & 0.191889 & 0.223444 & V48 & -0.42987 & 0.095859 & V49 & -0.6581 & 0.116565 & V49 & 0.375693 & 0.081053 \\
\hline V49 & 0.313734 & 0.292015 & V49 & 0.510747 & 0.040686 & V50 & 0.589116 & 0.115741 & V50 & 0.17624 & 0.057958 \\
\hline V50 & -0.07072 & 0.322083 & V50 & -0.15359 & 0.167179 & V51 & 0.156958 & 0.091861 & V51 & 0.26064 & 0.042262 \\
\hline V51 & -1.32612 & 0.376605 & V51 & -0.74128 & 0.152895 & V52 & -0.04862 & 0.154847 & V52 & 0.022633 & 0.051913 \\
\hline V52 & -1.55954 & 0.605217 & V52 & 0.722786 & 0.124867 & V53 & -0.08196 & 0.14251 & V53 & 0.243894 & 0.040478 \\
\hline V53 & -0.58731 & 0.50655 & V53 & -0.87398 & 0.205263 & V54 & 0.358909 & 0.300416 & V54 & -0.08103 & 0.047011 \\
\hline V54 & -1.52738 & 0.291525 & V54 & -2.80394 & 0.569351 & V55 & -1.39273 & 0.180166 & V55 & -1.68363 & 0.089302 \\
\hline V55 & 0.500171 & 0.263424 & V55 & -0.62457 & 0.061589 & V56 & 0.463065 & 0.115124 & V56 & -0.22361 & 0.243097 \\
\hline V56 & -0.84514 & 0.827344 & V56 & -0.28573 & 0.086037 & V57 & -0.17141 & 0.100042 & V57 & -0.12671 & 0.036937 \\
\hline V57 & -1.53567 & 0.5912 & V57 & -0.03266 & 0.105458 & & & & & & \\
\hline V58 & -1.502 & 0.437754 & V58 & 0.28164 & 0.238921 & & & & & & \\
\hline V59 & -0.61745 & 0.121944 & V59 & -0.02293 & 0.042288 & & & & & & \\
\hline V60 & -0.86962 & 0.2279 & V60 & -0.34729 & 0.056072 & & & & & & \\
\hline V61 & -1.13361 & 0.297701 & V61 & 0.499199 & 0.139124 & & & & & & \\
\hline \multirow[t]{15}{*}{ V62 } & -0.66242 & 0.242553 & V62 & -0.61919 & 0.189209 & & & & & & \\
\hline & & & V63 & 0.398914 & 0.16461 & & & & & & \\
\hline & & & V64 & -0.98317 & 0.192357 & & & & & & \\
\hline & & & V65 & 0.025723 & 0.295391 & & & & & & \\
\hline & & & V66 & 0.243105 & 0.264051 & & & & & & \\
\hline & & & V67 & -0.82149 & 0.092149 & & & & & & \\
\hline & & & V68 & 0.492983 & 0.061807 & & & & & & \\
\hline & & & V69 & -0.65974 & 0.053395 & & & & & & \\
\hline & & & V70 & -0.82806 & 0.176281 & & & & & & \\
\hline & & & V71 & -0.66735 & 0.12825 & & & & & & \\
\hline & & & V72 & -0.87664 & 0.031849 & & & & & & \\
\hline & & & V73 & 0.475948 & 0.031869 & & & & & & \\
\hline & & & V74 & -1.02825 & 0.223554 & & & & & & \\
\hline & & & V75 & -1.00291 & 0.119712 & & & & & & \\
\hline & & & V76 & 0.579746 & 0.088904 & & & & & & \\
\hline
\end{tabular}

641 